\title{
DEMOKRAT PARTI'NIN ATATÜRK FILMI PROJELERI
}

\author{
ATATÜRK FILM PROJECTS OF THE DEMOCRAT PARTY
}

\author{
Tunç BORAN*
}

Geliş Tarihi/Received:17.10.2020

Kabul Tarihi/Accepted:27.12.2020

BORAN, Tunç, (2021), “Demokrat Parti'nin Atatürk Filmi Projeleri”, Belgi Dergisi, S.21, Pamukkale Üniversitesi Atatürk Illkeleri ve İnkılâp Tarihi Araştırma ve Uygulama Merkezi Yayını, Kış 2021/I, ss. 253-277.

Öz

Atatürk'ün hayatını konu alan belgesel filmler bulunmasına karşın kurmaca bir Atatürk filmi çekilememiştir. Ancak sinema tarihinde kurmaca bir Atatürk filmi çekmek için pek çok girişim olmuştur. Bu başarısız Atatürk filmi girişimlerinin başlangıcı Demokrat Parti dönemidir. Demokrat Parti iktidarı döneminde, Türk Sinemasında daha önce denenmemiş bir büyük projeyi gerçekleştirmeyi planlamıştır. Atatürk'ün hayatını anlatan kurmaca bir film çekilmesini içeren proje, sinema vasıtası ile Atatürk'ü ve fikirlerini dünyaya tanıtmayı amaçlamışıı. Atatürk filmi projesinin fikir babası ve ardındaki irade dönemin Cumhurbaşkanı Celal Bayar'dır. Kurmaca bir Atatürk filmi için iki kez girişimde bulunulmuştur. Her iki girişimde de Atatürk filmi projesini gerçekleştirmek için Amerikalılara başvurulmuştur. Atatürk filmi girişimlerinde Amerikalılar ile Türk Hükümeti arasında aracılığı Amerika'da yaşayan Adil Özkaptan yapmıştır. 1954 yııında Amerikalı aktör ve film yapımcısı Douglas Fairbanks Jr. Atatürk filmi projesi için Türkiye'ye davet edilmiştir. Douglas Fairbanks Jr. bir haftalık gezisinde üst düzey bir protokol ile ağırlanmıștır. Fairbanks Jr'ın Atatürk filmi projesi, bir yıl süren senaryo yazım aşamasında iken akim kalmıştır. 1955 yılında Atatürk filmi projesi, bu defa Amerikalı Universal International Film Yapım şirketine sipariş edilmiştir. Universal şirketi 3 yıla yakın bir süre Atatürk filmi projesi üzerinde çalışmıştır. Atatürk rolü için dönemin Amerikalı ünlü aktörlerinin adı geçmiştir. Şirket, Türk Hükümetinden gelen talepler doğrultusunda filmin senaryosunda düzeltmeler yapmışır. Finansmanını Türkiye Cumhuriyeti Hükümeti'nin karşıladığı film projesi henüz senaryo aşamasında iken feshedilmiştir. Sunulan senaryoların Demokrat Parti iktidarı tarafından beğenilmemesi ve sürekli değişiklik talep edilmesi nedeniyle sözleşmeyi fesheden taraf film yapım şirketi olmuştur. Bu çalışmada, Demokrat Parti döneminde Amerikalılara yaptırılması planlanan Atatürk filmi projelerinin süreçleri aktarılacak, projelerin akıbetleri ve gerçekleşmeme nedenleri sorgulanacaktır.

Anahtar Kelimeler: Atatürk Filmi, Demokrat Parti, Celal Bayar, Biyografi Filmi, Hollywood.

*Dr. Öğr. Üyesi, Çankırı Karatekin Üniversitesi Sanat Tasarım ve Mimarlık Fakültesi, Sinema TV Bölümü, tuncboran@karatekin.edu.tr, (https://orcid.org/0000-0002-3055-0690). 


\begin{abstract}
Although there are documentary films about Atatürk's life, a fictional Atatürk film could not be shot. However, there have been many attempts to shoot a fictional Atatürk film in the history of cinema. Democrat Party period was the beginning of these unsuccessful attempts at Atatürk films. The Democrat Party, during its rule, wanted to realize an unprecedented big project in Turkish Cinema. The project, which involves explaining Atatürk's life with a fictional film, aimed to introduce Atatürk and his ideas to the world through cinema. The idea father of the Ataturk film project and the will behind it was the then President Celal Bayar. Two attempts were made for a fictional Ataturk movie. In both attempts, Americans were consulted to realize the Ataturk film project. Adil Özkaptan, who lives in America, made the mediation between the Americans and the Turkish Government in the Atatürk film initiatives. In 1954, American actor and filmmaker Douglas Fairbanks Jr. has been invited to Turkey for the Ataturk film project. Douglas Fairbanks Jr. was hosted in a high-level protocol on his one-week trip. Fairbanks Jr's Ataturk film project was left unfinished while the script was written for a year. In 1955, the Atatürk film project was commissioned this time to the American Universal International Film Production company. Universal company worked on the Ataturk film project for nearly 3 years. Famous American actors of the period were mentioned for the role of Atatürk. The company revised the script of the film in line with the requests from the Turkish Government. The budget of the film will be borne by the Government of the Republic of Turkey. The movie project was terminated while it was at the script stage. Due to the fact that the scenarios presented were not liked by the Democrat Party government and the demand for constant changes, there were film production companies that terminated the contract. In this study, the processes of Atatürk film projects planned to be made by the Americans during the Democratic Party period will be explained, the fate of the projects and the reasons for failure will be questioned.
\end{abstract}

Keywords: Ataturk Film, Democrat Party, Celal Bayar, Biography Film, Hollywood. 


\section{Giriş}

Modern Türk siyasi tarihi için 1950 yılının bir dönüm noktası olduğu yönünde tarihçiler arasında yaygın bir mutabakat vardır. O yııın Mayıs ayında yapılan seçimle 27 yıllık kurucu tek parti iktidarı sona ermiştir. Ciddi bir farkla seçimi kazanan Demokrat Parti, Mecliste çoğunluğu elde etmiş, sandıktan çıkan sonuçla iktidar sükûnet içinde el değiştirmiştir. ${ }^{1}$ Yeni Meclis, Demokrat Parti'nin kurucusu Celal Bayar'ı Cumhurbaşkanı seçmiştir. Başbakanlık için ise pek çok güçlü rakip arasından genç siyasetçi Adnan Menderes sıyrılmış ve Başbakanlığın yanı sıra Demokrat Parti Genel Başkanlığı görevini de üstlenmiştir. 27 yıl içinde Devlet Partisi-Parti Devletine dönüşen Cumhuriyet Halk Partisi muhalefet rolüne; kurucuları dışında kalan üyelerinin geçmişte iktidar merkezinin dışında kalan kesimlerden oluşmasından ötürü Demokrat Parti, iktidar rolüne uyum sağlamakta güçlük çekmiştir. İki parti arasındaki ilişkiler, ilk günlerden itibaren gergin başlamıştır. ${ }^{2}$ Siyasi rekabet içinde olan iki parti, Cumhuriyetin kurucu lideri Atatürk'ü de rekabet alanlarından birine dönüştürmüşlerdir. Atatürk'ün devrimlerine sadık kalma ve hatırasına sahip çıkma rekabetini başlatan taraf kuşkusuz Demokrat Parti olmuştur. Güçlü bir seçim zaferine rağmen Demokrat Parti yöneticilerinde, CHP Genel Başkanı İnönü’nün duruma razı olmadığına, bürokrasi ve ordu tarafından halen desteklendiğine dair kök salmış derin bir korku vardı. "Paşa faktörü" olarak tarif edilen bu korku, Demokrat Parti liderlerinin kendilerini güven içinde hissetmemelerine yol açıyordu. ${ }^{3}$ Demokrat Parti iktidara geldiği ilk günlerden itibaren CHP ve İsmet İnönü'nün karşında Atatürk üzerinden meşruiyet zemini aramıştır. Demokrat Parti iktidarı, Ebedi Şef ile Milli Şef arasında ince bir politik ayrım yaparak yalnızca İnönü dönemi mahkûm edilmiş ve İnönü, Atatürk'ü yeterince ortaya çıkarmadığı ve hatta unutturmaya çalıştığı iddia edilerek eleştirilmiştir. ${ }^{4}$ Demokrat Parti, Milli Şef İsmet İnönü'yü sıradan bir muhalefet liderine dönüştürmeye çalışırken Atatürk'ü ön plana çıkarmıştır. İnönü'nün kamusal alandaki otoritesini temsil eden eski dönemden kalma görünürlüğü (devlet dairelerinde, paradaki resimleri ve anıtları) ortadan kaldırılmıştır. Atatürk'ün ölümünden sonra paralara ve pullara Atatürk'ün yerine İnönü’nün fotoğrafı basılmıştı. Demokrat Parti iktidara gelir gelmez eski Cumhurbaşkanı İnönü’nün resimlerini, paralardan, pullardan çıkarıp yerine geçerli kanunlara uygun biçimde yeni Cumhurbaşkanı Bayar'ın değil Atatürk'ün resmini koymuştur. ${ }^{5}$ Atatürk'ün ölümünden sonra devlet dairelerinde Atatürk ile beraber dönemin Cumhurbaşkanı İnönü'nün resmi de asılmıştı. Bakanlar Kurulu, devlet dairelerinde yalnızca Türkiye Cumhuriyetinin kurucusu sıfatı ile Atatürk'ün resminin asılmasını kararlaştırmıştır. ${ }^{6}$ Cumhuriyet Halk Partisine ait Malatya Belediye Başkanlığı'nda İnönü’nün resminin asılı olması siyasi kriz yaratmış, Bakanlar Kurulu 23 Aralık 1950'de yayınlanan kararı ile resmi daire ve kurumlarda Atatürk'ten başkasının bilhassa İnönü'yü kast edilerek “onu istihlaf edenlerin portrelerinin" asılmaması gerektiğini hatırlatarak uyarmıştır.7 Demokrat Parti yanlısı basın, Çankaya Köşkü’nde Atatürk heykelinin yedi yıldır bir sandık içinde bırakıldığını iddia etmiş, ${ }^{8}$

1 Cem Eroğul, "Çok Partili Düzenin Kuruluşu 1945- 71," Geçiş Sürecinde Türkiye, Belge Yayınları, İstanbul, 1992, s. 119.

2 Erik Jan Zürcher, Modernleşen Türkiye'nin Tarihi, Çev: Yasemin Saner Gönen, İletişim Yayınları, İstanbul, 2007, s. 321-322;

3 Feroz Ahmad, Demokrasi Sürecinde Türkiye 1945-1980, Çev: Ahmet Fethi, Hil Yayını, İstanbul, 1996, s.48-49

4 Cemil Koçak, "Tek Parti Yönetimi, Kemalizm ve Şeflik Sistemi: Ebedi Şef/Milli Şef," Modern Türkiye'de Siyasi Düşünce Cilt: 2 Kemalizm, İletişim Yayınları, İstanbul, 2006, s. 137.

5 Hasan Ünder, "Atatürk İmgesinin Siyasal Yaşamdaki Rolü," Modern Türkiye'de Siyasi Düşünce Cilt: 2 Kemalizm, İletişim Yayınları, İstanbul, 2006, s. 153.

6 Zafer Gazetesi, 10 Haziran 1950

7 Zafer Gazetesi, 29 Aralık 1950

8 Zafer Gazetesi, 25 Haziran 1950 
bu heykel, 19 Mayıs 1951 tarihinde Çankaya Köşkü'nün bahçesine törenle dikilmiştir. ${ }^{9}$ Öte taraftan İnönü'nün Sivas Çimento Fabrikası'nda bulunan heykeli, Cumhurbaşkanı Bayar'ın ziyareti öncesi kaldırılmıştır. ${ }^{10}$ Elbette İnönü hedef alınarak yaşayanların heykellerinin dikilmesini ve adlarının cadde, meydan ve okullara verilmesini yasaklayan bir yasa çıkarılmıştır. ${ }^{11}$ Bir dini tarikatın Atatürk heykellerine yönelik saldırılarının ardından Demokrat Parti hükümeti, 1951'de "Atatürk Aleyhine Iş̧lenen Suçlar Hakkında Kanunu" çıkarmıştır. ${ }^{12}$ Atatürk'ün ölümünden sonra 12 yıl boyunca Atatürk'ün kabri "Anıtkabir" tamamlanamamıştı. Cumhurbaşkanı Bayar, Başbakan Menderes ile ilk ziyaretlerinden birini Anıtkabir inşaatına yaparak konuya verdikleri önemi kamuoyuna göstermiştir. Demokrat Parti döneminde, Anıtkabir inşaatı hızlandırılmış ve üç buçuk yılda Anıtkabir inşaatı tamamlanmıştır. 10 Kasım 1953 günü düzenlenen Anıtkabir'e Nakil Töreni, 15 yıl sonra yapılan ikinci bir cenaze töreni olarak düzenlenmiştir. Ölümünün üzerinden on beş yıl geçmiş olmasına rağmen tören, Atatürk'ü kaybetmiş olmanın hüznünü yeniden yaşatmıştır. Anıtkabir ve Nakil Töreni Demokrat Parti'nin Atatürk'ün mirasına ve ilkelerine sahip çıktığını gösteren siyasal bir zemine dönüştürülmüştür. ${ }^{13}$ Demokrat Parti, CHP'yi Atatürk sevgisini unutturmakla, on iki yıl Anıtkabir'i yapmamakla suçlamıştır. CHP'nin ve İnönü'nün Anıtkabir inşaatını sürüncemede bırakarak Atatürk'ün manevi varlığına saygısızlık yaptıkları, DP'nin ise Anıtkabir inşaatını tamamlayarak Atatürk'e sahip çıktığı ileri sürülmüştür. İnönü'yü sıradan bir muhalefet liderine dönüştürmeyi hedefleyen bu hamleler aynı zamanda kurucu lider Atatürk ile CHP arasındaki bütünlüğü ortadan kaldırmayı da amaçlamıştır. Anıtkabir'e Nakil Töreninden on gün sonra Başbakan Adnan Menderes, “Atatürk'ün ne Halk Partisi'nin ne de Demokrat Parti'nin ya da herhangi bir kimsenin veya zümrenin malı olmadığını"14 beyan etmiştir. Atatürk'ü partiler üstü bir simgeye dönüştürmek, DP'ye siyasi rakibi CHP ile Atatürk arasındaki bağı kopartmaya destek vermiştir.

Demokrat Parti, Atatürk'e bağlılık konusunda yaptığı hamlelerden birisini 1954 Milletvekili Genel Seçimlerinden kısa bir süre önce gerçekleştirmiştir. O tarihe kadar Atatürk'ün hayatı hakkında bir belgesel hazırlanmamıştır. Atatürk'ün sağığında yurt içi gezileri, törenleri, günlük faaliyetleri filme alınmıştı ancak ne sağlığında ne de ölümünden sonra hayatını konu alan bir belgesel yapılmamıştır. Demokrat Parti iktidarı daha doğru bir ifade ile Cumhurbaşkanı Celal Bayar, arşiv görüntülerinden derlenen ilk Atatürk belgeselini hazırlatmıştır. Yönetmenliğini Münir Hayri Egeli'nin yaptığı "Atatürk Sevgisi” adını taşıyan 45 dakikalık filmin kurgusu Almanya' da yapılmıştır. "Atatürk Sevgisi” filminin finansmanını İ̧̧ Bankası sağlamıştır. İ̧̧ Bankası'nın kurucusu ve dönemin Cumhurbaşkanı Celal Bayar'ın filmin finansmanı ve gerçekleşmesinde etkin olduğu şüphesizdir. "Atatürk Sevgisi" filmi, seçimlerden bir hafta önce 23 Nisan 1954 Cuma günü sinemalarda gösterime girmiştir. "Atatürk Sevgisi" filmi Atatürk'ün hayatını konu almaktan çok Atatürk ve Bayar ilişkisine odaklanmaktadır. Atatürk'ün fikirlerinin ve ideallerinin takipçisinin Cumhurbaşkanı Bayar olduğu fikri işlenmektedir. Bayar'ın siyasi rakibi İnönü filmde hiç görülmemektedir. Toplumsal, kültürel devrimlerden hiç söz etmeyen film, Atatürk döneminde ve Demokrat Parti döneminde yapılan ekonomik hamlelere yoğunlaşmaktadır. ${ }^{15}$ Filmi, Demokrat

9 Zafer Gazetesi, 20 Mayıs 1951

10 Ulus Gazetesi, 3 Ekim 1950

11 Ahmad, a.g.e. s.57.

12 Zafer Gazetesi, 24 Temmuz 1951; Ulus Gazetesi, 26 Temmuz 1951: Milliyet Gazetesi, 26 Temmuz 1951.

13 Tunç Boran, Mekân ve Siyaset Bağlamında Anıtkabir, Yayınlanmamış Doktora Tezi, Ankara Üniversitesi Türk İnkılap Tarihi Enstitüsü, Ankara, 2011, s.330-331.

14 Milliyet Gazetesi, 21 Kasım 1953

15 Tunç Boran, "Türk Sinema Tarihinden İlgi Çekici Bir İddianın İncelenmesi,” Türk Sinema Tarihine Farklı Bakışlar, Detay Yayıncılık, Ankara, 2020,s.18-19. 
Parti'nin propagandası olarak gören Nijat Özön'e göre film, zengin malzemenin sorumsuz ellerde nasıl harcandığını ortaya koymaktan başka bir özellik taşımamaktadır. ${ }^{16}$

Seçimden evvel "Atatürk Sevgisi'ni" vizyona sokan Demokrat Parti, 1954 seçiminde sandıktan büyük bir zaferle çıkmışır. Bu güçlü zaferin ardından Cumhurbaşkanı Celal Bayar, Atatürk ile ilgili yine daha önce denenmemiş bir girişime imza atmıştır. Atatürk'ün hayatını kurmaca bir film ile anlatma ve Atatürk'ü beyazperdede canlandırma projesini gerçekleştirmek için harekete geçilmiştir. Demokrat Parti döneminde kurmaca bir Atatürk filmi için iki kez girişimde bulunulmuştur. Her iki girişimde de Atatürk film projesini gerçekleştirmek için Amerikalılara başvurulmuştur. Bu çalışma, Demokrat Parti döneminde gerçekleştirilmeye çalışılan Atatürk filmi projelerini konu edinmektedir. Çalışmanın amacı, Amerikalılara yaptırılması planlanan Atatürk filmi ile ilgili projelerin süreçlerini aktarmak ve projelerin gerçekleşmeme sebeplerini sorgulamaktır. Çalışmayı önemli kılan unsur bu konu hakkında daha önce akademik bir çalışmanın yapılmamış olmasıdır. Çalışma, literatürdeki boşluğu doldurarak ileride yapılacak çalışmalar için bir yol haritası sunmayı amaçlamaktadır.

\section{Atatürk Filmi İçin Illk Girişim: “ince Bıyık” Douglas Fairbanks Jr.}

Türk tarihinin ve Atatürk'ün hayatının önemli bir dönüm noktası olan Kurtuluş Savaşı çok erken bir dönemde beyazperdede canlandırılmıştır. Henüz 1923 tarihinde Kurtuluş Savaşında geçen bir öyküyü perdeye taşıyan "Ateşten Gömlek" filmi seyirci ile buluşmuştur. Halide Edip Adıvar'ın aynı adlı romanından uyarlanan filmin yönetmenliğini Muhsin Ertuğrul yapmıştır. Kurtuluş Savaşının anılarının henüz çok taze olduğu bir dönemde yapılan filmde, Türk kadın oyuncular da rol almıştır. ${ }^{17} 1929$ yılında Muhsin Ertuğrul, Reşat Nuri Güntekin tarafından bir Fransız oyunundan "Bir Gece Faciası" adıyla uyarlanan senaryoyla yola çıkarak "Ankara Postası" adlı filmi çekmiştir. İlk sesli Kurtuluş Savaşı temalı film de Muhsin Ertuğrul'un yönetmenliğinde çekilmiştir. Bu defa özgün bir senaryoya dayanan "Bir Millet Uyanıyor" adlı film, Muhsin Ertuğrul'un "anılmaya değer" filmlerinden biri sayılmaktadır. 1932 tarihli filmin son sekansında Milli Mücadele ile ilgili belge görüntüler yer almaktadır. Daha sonraki Kurtuluş Savaşı filmlerinde de tekrarlanan bu tercih nedeni ile Onaran, "Bir Millet Uyanıyor" filminin Kurtuluş Savaşı filmleri için "prototip" oluşturduğunu düşünmektedir. ${ }^{18}$ Muhsin Ertuğrul'un Kurtuluş Savaşı filmlerinin ilk örneklerini vermesinin ardından Türk sinemasında üretilen film sayısının arttığı ve yeni yönetmenlerin ortaya çıktığı 1940'ların ikinci yarısında yeni Kurtuluş Savaşı filmleri de çekilmiştir. Şakir Sırmalı́nın ilk filmi "Domaniç Yolcusu/ Unutulan Sır" romandan uyarlanmıştır. Çekimleri 1945 'te başlayan ancak 1948'de gösterime giren film, Kurtuluş Savaşı'nda geçen bir olayı geriye dönüşlerle anlatmaktadır. Scognamillo'ya göre, filmin anlatımı o kadar başarısızdır ki yıllar boyunca Türk Sinemasında "geriye dönüşü" adeta yasaklatmıştıs. ${ }^{19} 1948$ yılının bir diğer Kurtuluş Savaşı filmi, Ferdi Tayfur'un yönettiği "Istiklal Madalyası" adlı yapımdır. Filmde, kalabalık savaş sahneleri için Ordu'nun da desteği alınmıştır. Bu filmler, Nijat Özön'ün tabiri ile Kurtuluş Savaşı filmleri çığırını açmıştır. ${ }^{20}$ Döneme damga vuran "Vurun Kahpeye" adlı Kurtuluş Savaşı temalı yapım, Lütfi Ö. Akad'ın da ilk filmidir. Seyirciden büyük ilgi gören film, kimi kesimlerce de tepkiyle karşılanmıştır. ${ }^{21}$ Amerika'da sinema eğitimi almış olan Turgut Demirağ'ın "Fato-Ya Istiklal Ya Ölüm” dönemin başarılı Kurtuluş

16 Nijat Özön, Türk Sineması Tarihi, 1896-1960, Artist Yayınları, İstanbul, 1962, s.236.

17 Fikret Hakan, Türk Sinema Tarihi, İnkılap Kitabevi, İstanbul, 2012, s.47.

18 Âlim Şerif Onaran, Muhsin Ertuğrul'un Sineması, Kültür Bakanlığı Yayınları, Ankara,1981, s.183-202.

19 Giovanni Scognamillo, Türk Sinema Tarihi, Kabalcı Yayınevi, İstanbul, 2010, s.104.

20 Nijat Özön, Türk Sineması Kronolojisi 1895-1966, Bilgi Yayınevi, İstanbul, 1968, s.96

21 Agah Özgüç, Türlerle Türk Sineması, Dünya Kitapları, İstanbul, 2005, s.86-87. 
Savaşı temalı filmlerinden biridir. 22 "Ateşten Gömlek'in" Vedat Örfi Bengü tarafından ikinci çevrimi, Çetin Karamanbey'in "Çete", Orhan Arıburnu'nun "Yüzbaşı Tahsin" 1950 yapımı Kurtuluş Savaşı filmleridir. ${ }^{23}$ Sami Ayanoğlu'nun "Allahaısmarladık" (1951), Nuri Akıncı'nın "Ege Kahramanları" (1951), Kani Kıpçak'ın "Istanbul Kan Ağlarken" (1951), Faruk Kenç'in "Kendini Kurtaran Şehir- Şanlı Maraş" (1951), Orhan Arıburnu'nun "Sürgün" (1951), Aydın Arakon'un "Vatan Için" (1951), Seyfi Havaeri'nin "Destan Destan Içinde" (1952), Mümtaz Ener'in "Hürriyet Için” (1952), Lütfi Ö. Akad’ın “ingiliz Kemal Lawrens'e Karşı" (1952), Nusret Eraslan'ın "Kocatepe'nin Beş At/ııı" (1952), Seyfi Havaeri'nin "Zafer Güneşi” (1953), Muharrem Gürses'in "Hürriyet Uğrunda" (1954) ve Hayri Esen'in "istiklal Harbi" (1954) 1950'li yılların ilk yarısında Türk Sinemasındaki tarihi film furyasında çekilen Kurtuluş Savaşı temalı filmlerdir. ${ }^{24}$ Türk Sinemasında başlangıçtan 1954 yılına kadar konusu Kurtuluş Savaşı yıllarında geçen 23 film yapılmıştır. Kurtuluş Savaşı filmlerinin kimisinde Mustafa Kemal Atatürk'ten isim olarak bahsedilirken kimisinde de Atatürk'ün belge görüntüsü veya fotoğrafları kullanılmıştır. Bu filmlerin hiçbirinde Atatürk, herhangi bir yasak olmamasına rağmen bir aktör tarafından canlandırılmamıştır. Üstelik bu filmler, Atatürk biyografisi veya Atatürk'ün hayatının Kurtuluş Savaşındaki döneminden bir kesiti sunmayı amaçlayan yapımlar da değillerdir.

1954 yılındaki büyük seçim zaferinin ardından Demokrat Parti iktidarı, Türk sinemasında daha önce denenmemiş bir projeyi gerçekleştirmek için harekete geçmiştir. Bu proje, Türkiye Cumhuriyeti'nin kurucusu Atatürk'ün hayatını beyazperdede canlandırmayı ve ortaya çıkan kurmaca film yoluyla Atatürk'ü ve fikirlerini dünyaya tanıtmayı amaçlamaktadır. Atatürk filmi projesinin fikir babası ve ardındaki irade kesinlikle dönemin Cumhurbaşkanı Celal Bayar'dır. Bayar'ın bu projeye neden ihtiyaç duyduğu veya projenin zihninde ne zaman ve nasıl oluştuğuna dair bir bilgi, belge veya hatırat bulunmamaktadır. Atatürk'ün hayatına dair film projesi, Bayar'ın çok önceden beri zihnini meşgul eden bir proje olabileceği gibi aktüel olayların Atatürk filmi projesinin oluşmasında tesiri olabilir. 1954 yılının Ocak-Şubat ayında Cumhurbaşkanı Bayar, yolculuk süresi de dâhil 50 günlük $A B D$ gezisine çıkmıştır. ${ }^{25}$ Bu uzun gezide, Bayar, ABD'nin belli başlı büyük şehirlerini ziyaret etmiştir. Los Angeles'ı da ziyaret eden Bayar, Hollywood stüdyolarını gezmiştir. Universal stüdyolarını gezen Bayar, Hun İmparatoru Atilla'nın hayatını anlatan filmin ${ }^{26}$ çekimlerine tesadüf etmiş, filmde rol alan oyuncular ile görüşmüştür. ${ }^{27}$ Böylelikle Bayar, film endüstrisini yakından görmüştür. Bu ziyaretten ve tesadüf ettiği biyografi filmden Bayar'ın ne ölçüde etkilendiği bilinmez ancak devlet adamlarının ve tarihi kişiliklerin biyografileri 1950'li yılların ilk yarısında Hollywood'da popüler bir türdü. Marlon Brando'nun oynadığı Joseph L. Mankiewicz 'in yönettiği "Julius Caesar" (1953), Martin Luther'in hayatını anlatan Amerikan-Batı Alman ortak yapımı "Martin Luther" (1953), Almanların ünlü komutanı Erwin Rommel'i anlatan "Çöl Tilkisi" (1951), Florence Nightingale'in hayatını anlatan "Lambalı Kadın” (1951), Elia Kazan'ın yönettiği Meksikalı ünlü devrimci Emiliano Zapata'nın öyküsünü anlatan "Viva Zapata" (1952) bu filmlerden yalnızca bir kaçıdır. ${ }^{28}$ Elbette Bayar'ın bu biyografi filmlerinden habersiz olması düşünülemez.

22 Scognamillo, a.g.e., s.98.

23 Erman Şener, Kurtuluş Savaşı ve Sinemamız, Ahmet Sarı Matbaası, İstanbul, 1970, s. 54-56.

24 Agah Özgüç, Ansiklopedik Türk Filmleri Sözlüğü, Horizon International, İstanbul, 2012, s.52-74.

25 Erden Eren Erdem, “Türkiye-ABD İlişkilerinin Zirve Noktası: Celal Bayar’ın ABD Ziyareti,” Türkiye'nin 1950’li Yılları, illetişim Yayınları, İstanbul, 2016, s.141.

26 Bu film, başrollerini Anthony Quinn ve Sophia Loren'in paylaşttkları 1954 yapımı "Attila" olmalıdır.

27 Akşam Gazetesi, 10 Şubat 1954, s.1-2.

28 Rekin Teksoy, Sinema Tarihi Cilt:1, Oğlak Yayınları, İstanbul, 2009, s. 360-383 
Cumhurbaşkanı Celal Bayar, zihnindeki Atatürk filmi projesini hayata geçirebilmek için Amerikalı oyuncu, prodüktör Douglas Fairbanks Jr.'ı Türkiye'ye davet etmiştir. 14 Ağustos 1954 günü kendisi gibi oyuncu olan eşi Mary Lee ile birlikte Türkiye'ye gelen Douglas Fairbanks Jr. Yeşilköy Havaalanı'nda devlet töreni ile Cumhurbaşkanı adına Yaver Binbaşı Kenan Yazgan, İstanbul Valisi adına Özel Kalem Müdürü Nabi Up, Türk sanatçılar, hayranlar ve basın mensuplarının oluşturduğu geniş bir kalabalık tarafından karşılanmış ve Cumhurbaşkanı adına çiçek takdim edilmiştir. Havaalanında yaptığı ilk açıklamada, "bütün dünyada tanınan büyük bir dahi ve kahramanın hayatını filme almanın gayet zor ve cesaret isteyen bir teşebbüs" olduğunu söyleyen Fairbanks, Türk Hükümeti'nin hazırlanacak senaryoyu onaylaması halinde Atatürk filminin çekimine 1955 yılında başlanacağını duyurmuştur. Kemal Atatürk rolünü oynayacak aktörü bir jüri heyeti belirleyecek, Douglas Fairbanks Jr. ise Atatürk filminde rol almayacak, yapımcılığını üstlenecektir. ${ }^{29}$

Devlet töreni ile karşılanan Douglas Fairbanks Jr. bir haftalık gezisinde üst düzey protokol ile ağırlanmıştır. Fairbanks'e Küçüksu Kasrı tahsis edilmiş, Cumhurbaşkanı Celal Bayar Amerikalı aktörü Florya Köşkü'nde kabul etmiştir. Öğle yemeğinde Atatürk filmi hakkında konuşan ikili, birlikte yelken ve motor yarışlarını izlemiştir. İstanbul sosyetesi, Amerikalı aktör şerefine Moda Deniz Kulübü'nde ziyafet vermiştir. ${ }^{30}$ Douglas Fairbanks Jr. İstanbul'un camilerini, saraylarını gezmiş, İstanbul Vali'sini ziyaret etmiştir. ${ }^{31}$ Boğazda yat gezintisi yapmış, hatta bir sünnet dügününe bile katılmıştır. ${ }^{32}$ Fairbanks, Türkiye ziyaretinde hızlı bir Ankara turu da yapmıştır. Toplam 420 dakika kaldığı Ankara'da yine devlet töreni ile karşılanmıştır. Anıtkabir'i ziyaret etmiş, Özel Deftere; "Türk milletinin kurucusu Atatürk'ü ziyaret edebilmek fırsatını bulduğum için son derece müftehirim" yazmıştır. Çankaya Köşkü'nü gezmiş, orada Celal Bayar'la Atatürk'ün beraber çekilmiş resimlerini gören Fairbanks, iki büyük adamın ne kadar dost olduklarını daha iyi anladığını ifade etmiştir. Büyük Sinemada Atatürk'ün sağlığında çekilmiş filmlerden parçalar seyretmiştir. Başbakan Yardımcısı Fatin Rüştü Zorlu ile Marmara Köşkü'nde öğle yemeği yemiştir. Genelkurmay Başkanı Orgeneral Nurettin Baransel'i, Basın-Yayın ve Turizm Kurumu'nu ziyaret etmiştir. ${ }^{33}$

Küçüksu Kasrında Türk Folklor Ekipleri Fairbanks için özel gösteri düzenlemiştir. ${ }^{34}$ Fairbanks'e devletin gösterdiği ilgi, üst düzey protokol seviyesini bile zorlayacak düzeydedir. Amerikalı aktörün "şerefine" askeri tatbikat bile düzenlenmiştir. İstanbul Mecidiyeköy'de tankların, piyade ve süvari erlerinin katıldıkları askeri tatbikatı, Fairbanks keyifle izlemiştir. ${ }^{35}$

Gazetelerin "sinema dünyasının en tanınmış yıldız ve prodüktörlerinden" olarak tanımladıkları Douglas Fairbanks Jr.'a gösterilen büyük hürmeti eleştirenler de olmuştur. Burhan Felek, Amerikalı aktörü, "ismi film artisti olmaktan ziyade bıyık modası salmakla meşhur Amerikalı sinema artisti müteveffa Douglas Fairbanks'ın oğlu küçük Fairbanks" olarak tanımlamaktadır. Burhan Felek'e göre; Fairbanks Jr. Atatürk filmini çevirecek birinci sınıf bir artist değildir. Türkiye'ye pek çok yabancı siyasi misafirin geldiğini ancak 29 Akis Dergisi, Sayı:15, 21 Ağustos 1954, s.9; Cumhuriyet Gazetesi, 15 Ağustos 1954, s.1-6; Milliyet Gazetesi, 15 Ağustos 1954, s.1-3.

30 Cumhuriyet Gazetesi, 16 Ağustos 1954, s.1; Milliyet Gazetesi, 16 Ağustos 1954, s.1; Akis Dergisi, Sayı:15, 21 Ağustos 1954, s.9.

31 Cumhuriyet Gazetesi, 17 Ağustos 1954, s.7.

32 Cumhuriyet Gazetesi, 18 Ağustos 1954, s.3.

33 Akis Dergisi, Sayı:15, 21 Ağustos 1954, s.9; Cumhuriyet Gazetesi, 19 Ağustos 1954, s.1; Milliyet Gazetesi, 19 Ağustos 1954, s.3.

34 Cumhuriyet Gazetesi, 23 Ağustos 1954, s.1.

35 Cumhuriyet Gazetesi, 20 Ağustos 1954, s.6. 
hükümdarlara Milli Sarayların tahsis edildiğini hatırlatmıştır. "Anlaşılan Amerikalı sevimli misafirimize Park Otelde yer bulunamamış" diyen yazar, Amerikalı aktöre Küçüksu Kasrının tahsis edilmesine şiddetle karşı çıkmıştır. ${ }^{36}$ Muhalif Akis dergisi, Fairbanks'in Otel yerine Küçüksu Kasrında ağırlanmasını "şark işi misafirperverlik" olarak değerlendirmiştir. ${ }^{37}$

Douglas Fairbanks Jr., Burhan Felek'in ifade ettiği gibi bıyıkları ile ünlü Amerikalı aktör Douglas Fairbanks'in oğlu idi. Hollywood sinemasının ilk popüler aktörlerinden olan Douglas Fairbanks, Zorro, Kara Korsan, Üç Silahşörler, Robin Hood adlı aksiyon filmlerinin kahramanıydı. Oğul Douglas Fairbanks Jr., babasının izinden giderek aktör olmuş, 1954 yılına kadar 60 filmde rol almıştır. Ancak hiçbir zaman babasının şöhretini yakalayamamıştır. ${ }^{38}$ Douglas Fairbanks Jr. aynı zamanda savaş kahramanıdır. İkinci Dünya Savaşı'nda Amerika Birleşik Devletleri Deniz Kuvvetleri'ne katılmış, birçok nişanla ödüllendirilmiştir. ABD Dışişleri Bakanlığı'nda bir süre görev yapmıştır. İkinci Dünya Savaşı'ndan sonra Londra'da ikamet eden Fairbanks Jr., kurduğu küçük film şirketi ile televizyona filmler çekmiştir. Her ne kadar sinema dünyasında çok ünlü olmasa da Avrupa hanedanları ve sosyetesi arasında popülerdir. Fairbanks o denli popülerdi ki, İngiltere Kraliyet ailesi onun için boşanmış insanlara karşı sert tutumunu bile yumuşatmıştır. Boşanmış insanları davetlere kesinlikle kabul etmeyen Ingiltere Kraliçesi bu kuralı Fairbanks Jr. için bozmuştur. Fairbanks Jr. ve eşi Mary Lee, daha önce evlenmiş ve boşanmış olmalarına rağmen İngiltere Kraliçesi tarafından yemek ve balolara davet edilmiştir. İngiltere, Batı Almanya, Fransa, İtalya ve Brezilya hükümetleri Fairbanks Jr.'a özel nişanlar vermiştir. ${ }^{39}$ Douglas Fairbanks Jr. beyazperdede değil ama siyaset ve iş dünyasında başarılı biridir. Zaten Türkiye'yi ziyaret ettiği 1954 yılında, sinema dünyasında kariyerini tamamlamış, televizyon, iş ve sosyetede adı anılan bir isim haline gelmiştir.

Douglas Fairbanks Jr., ziyareti sırasında gazetecilere açıklamalarda bulunmuş, basın toplantıları düzenlemiştir. Kimi zaman Atatürk hakkında film yapma fikrinin ilk defa 7-8 ay kadar önce kafasına girdiğini, ${ }^{40}$ kimi zaman da Türkiye ve Türkler hakkında 4 yıldır çalıştığını söylemiştir. ${ }^{41}$ Bazen de Türkiye'ye ilgisini çok genç yaşlarına kadar götürmüştür. ${ }^{42}$ Türkiye ve Atatürk hakkında çok şey bildiğini hatta anlatılanları bazen düzelttiğini iddia etmiştir. ${ }^{43}$ Her fırsatta Atatürk'ü övmüş, kendisini "en samimi Atatürk hayranı" ilan etmiştir. Her konuşmasında Atatürk'ü "Büyük Dâhi" olarak anmıştır. Atatürk'ü şu sözlerle övmüştür: "Hiçbir kumandan, büyüklügünü Atatürk'ün kadar dar imkânlarla gösterememiştir. Onu tanıdıktan sonra Türklerin neden izinde gittiklerini keşfetmem mümkün oldu ve Atatürk'e bir Türk kadar hürmet beslemeğe başladım." 44

Fairbanks'in Atatürk ile ilgili duygularının samimiyetini bilemesek de Atatürk filmi fikrinin Fairbanks'in kendi kendine geliştirdiği bir proje olmadığı muhakkaktır. Douglas Fairbanks Jr., Londra'da Türk işadamı Adil Özkaptan ile tanışmış, Adil Özkaptan'ın Atatürk'ün hayatı ile ilgili film yapma teklifini kabul etmiştir. Cumhurbaşkanı Celal Bayar, tasarı halinde bile olmayan Atatürk filmi projesi için Fairbanks'i Türkiye’ye davet etmiştir. Akis dergisinin ifade ettiği gibi Douglas Fairbanks Jr.'a Atatürk hakkında bir film çevirmesi

36 Burhan Felek, "Küçük Fairbanks," Hadiseler Arasında Felek, Cumhuriyet Gazetesi, 17 Ağustos 1954, s.3.

37 Akis Dergisi, Sayı:15, 21 Ağustos 1954, s.9

38 Teksoy, a.g.e., s.102.

39 Cumhuriyet Gazetesi, 24 Haziran 1957, s.5.

40 Cumhuriyet Gazetesi, 19 Ağustos 1954, s.1.

41 Cumhuriyet Gazetesi, 20 Ağustos 1954, s.6.

42 Cumhuriyet Gazetesi, 15 Ağustos 1954, s.6.

43 Akis Dergisi, Sayı:15, 21 Ağustos 1954, s.9

44 Cumhuriyet Gazetesi, 20 Ağustos 1954, s.6. 
böylelikle "ilham” edilmiş ve sanatçı da bunu ilgiyle karşılamıştır. ${ }^{45}$ Adil Özkaptan'ın Atatürk filmi projelerinde ilk aracılığı Douglas Fairbanks Jr. ile gerçekleşmiştir.

Fairbanks, henüz ortada olmayan Atatürk filmi projesi konusunda da gazetecileri bilgilendirmeyi ihmal etmemiştir. IllkişolarakAtatürk hakkındaki dokümanları toplayacağını, Kemal Atatürk hakkında ne bulursa beraberinde götüreceğini söylemiştir. Oysa Türkiye'den ayrılırken Fairbanks'in yanında Atatürk'ün sağlığında çekilmiş bazı görüntüler ve İngilizce Nutuk dışında hiçbir şey yoktur. Atatürk'ün hayatının çocukluğundan başlayarak bütün detayları ile inceleneceğini, filmin ön hazırlığının bir yıl süreceğini anlatmıştır. Nasıl bir senaryo düşünüyorsunuz sorusuna ise ya Atatürk'ün hayatını çocukluğundan itibaren beyaz perdeye aktarmayı, ya da hayatının sadece belirli bir bölümünü ele alacağız diye yanıtlamıştır. Zaten üçüncü bir şıkta bulunmamaktadır. Senaryonun gerekli olgunluğa ulaşamazsa girişimden vazgeçileceğini de söylemeden geçememiştir. ${ }^{46}$

Fairbanks, Atatürk filminin özel sermaye ile Türk-Amerikan işbirliği ile çevrileceğini, Türkiye içindeki masrafların Türk ve Türkiye dışındaki masrafların da Birleşik Amerikalı ve İngiliz ortaklar tarafından karşılanacağını ifade etmiştir. Atatürk filmine Türk hükümetinin dahlinin, sadece denetim ve kontrol açısından olacağını ve Türkiye'nin döviz kaybının olmayacağının altını çizmiştir. ${ }^{47}$ Fairbanks uyanık bir işadamı olarak görülmek istemiyordu. Ancak yine de Fairbanks'in belirttiği gibi film Türkiye' de çekilecektir. Bu durumda masrafın ağırlıklı kısmı, Türk hükümetine kalacağı açıktır. Bir iki başrol dışında filmde Türk oyuncular görev alacaktır. Fairbanks ise beyazperdede şimdilik görünmek istememektir. ${ }^{48} \mathrm{O}$ dönem ve sonraki yıllarda Türkiye'de zannedildiği gibi Fairbanks, Atatürk rolünü canlandırmak için gelmemiştir.

Fairbanks basın toplantısında, Türkiye ziyaretinin nedenini yalnızca Atatürk filmi olmadığını da belirtmiştir. Demokrat Parti döneminde çıkarılan Yabancı Sermayeyi Koruma Kanunu ile yabancılara Türkiye'de çok geniş imkânlar sağlandığını hatırlatmıştır. Film yapımcılı̆̆ının yanı sıra inşaat müteahhitliği ve inşaat malzemesi satışı işi ile de ilgilendiğini belirten Fairbanks, ziyaretinin bir sebebinin de bu sektörlerde iş bulmak olduğunu ifade etmiştir. ${ }^{49}$ Fairbanks, bir centilmene yakışacak şekilde dürüst davranmaktadır. İ̧̧adamı olarak Fairbanks, ilk aracılık ve komisyonculuk girişiminde bulunmakta gecikmemiştir. Ambassador Otelleri yetkilileri Çırağan Sarayı'nı lüks bir otele dönüştürme projesi ile İstanbul'a gelmiştir. Basına göre, Fairbanks'in bu işte aracılığı ve rolü olmuştur. ${ }^{50}$ Ancak proje hayata geçememiştir. ${ }^{51}$

Fairbanks'in Atatürk filmi projesi, Türkiye'de geniş yankı bulmuştur. Demokrat Parti'nin kontrolünde faaliyet gösteren Milli Türk Talebe Birliği henüz çekilmemiş Atatürk filmi için Fairbanks'e teşekkür telgrafı göndermiştir. Filmde, "Atatürk'ün dinamizmini, yüksek insani vasıflarını, sulhseverliğini, inkılapçılığını ve çok sevdiğini her fırsatta izhar ettiği inkılapların ve Cumhuriyetin bekçisi Türk gençliği ile olan yakın ve ulvî bağlıı̆ını belirtmesini" istemişlerdir. ${ }^{52}$ Bu kısa telgraf, Atatürk filminden beklentinin ne kadar yüksek ve konu itibariyle de geniş bir saha içerdiğinin ispatıdır.

45 Akis Dergisi, Sayı:15, 21 Ağustos 1954, s.9.

46 Cumhuriyet Gazetesi, 19 Ağustos 1954, s.1.

47 Cumhuriyet Gazetesi, 20 Ağustos 1954, s.6; Milliyet Gazetesi, 20 Ağustos 1954, s.3.

48 Cumhuriyet Gazetesi, 19 Ağustos 1954, s.1.

49 Cumhuriyet Gazetesi, 20 Ağustos 1954, s.6: Milliyet Gazetesi, 20 Ağustos 1954, s.3.

50 Milliyet Gazetesi, 28 Mayıs 1955, s.7.

51 Milliyet Gazetesi, 17 Haziran 1956, s.5.

52 Cumhuriyet Gazetesi, 17 Ağustos 1954, s.7. 
Douglas Fairbanks Jr. bir hafta süren keyifli tatilin ardından 22 Ağustos 1954 günü Türkiye'den ayrılarak Londra'ya gitmiştir. Ayrılırken başta Cumhurbaşkanı Celal Bayar olmak üzere Türk büyüklerine gösterdikleri samimiyet ve misafirperverliğe teşekkür etmiştir. ${ }^{53}$

1954 yılının Ekim ayında Fairbanks'in Türk ortağı olduğunu iddia eden Adil Özkaptan, Atatürk filmi ile ilgili açıklamalarda bulunmuştur. Özkaptan, aralarında iki Oscar ödüllü Amerikalı oyuncu Fredric March'ın da bulunduğu birçok popüler oyuncunun Atatürk rolünü oynamak için müracaat ettiğini iddia etmiştir. Douglas Fairbanks Jr. ise Atatürk rolü için March'ı yaşlı bulmaktadır. Atatürk rolünü ünlü İngiliz oyuncu Laurence Olivier'in canlandıracağını açıklamıştır. Filmin senaryosunu ise, usta bir senarist olan Howard Hawks hazırlayacaktır. Özkaptan, senaryodan önce filmin öyküsünü (Sinopsisi) Amerikalı yazar Elizabeth Downing'in yazacağını duyurmuştur. Downing, Cumhurbaşkanı Bayar'ın tespit edeceği 6 Türk yazar ile görüşerek filmin öyküsünü yazacaktır. ${ }^{54}$ Ancak kısa bir süre sonra Elizabeth Downing'in yerine Bridget Boland'ın filmin öyküsünü yazacağı açıklanmıştır. ${ }^{55}$

3 Kasım 1954 günü Atatürk filminin bir başka ortağı Aubrey Baring, Türkiye'ye gelmiştir. Baring, Atatürk filminin 4 Milyon Türk Lirasına mal olacağını açıklamıştır. Filmin Türkiye dışındaki masraflarını Fairbanks ile birlikte finanse edeceklerini duyurmuştur. Baring, filmin tamamının Türkiye'de çekileceğini elbette değinmemiştir. Renkli çekilecek olan Atatürk filmi, herhangi bir engel çıkmadığı takdirde 15 ay sonra tamamlanacaktır. Bridget Boland, Douglas Fairbanks Jr.'un 4 seneden beri toplamakta olduğu dokümanlardan istifade ederek filmin hikâyesinin iskeletini kaleme alacaktır. Bu hikâye, Bakanlar Kuruluna sunulacak, kabul olunduğu takdirde Bridget Boland Türkiye'ye gelecek ve Cumhurbaşkanı Celal Bayar'ın Atatürk'ün yakın arkadaşları arasında seçeceği 6 Türk yazar ile görüşerek filmin hikâyesini hazırlayacaktır. Bayar, Atatürk ile ilgili bir hatıra koleksiyonunu Bridget Boland için hazırlatmaktadır. Henüz bir sinopsis bile ortada olmasa da Aubrey Baring, Atatürk filminin prömiyerini bile düşünmüştür. Hollywood'dakilere benzer birer büyük törenle Ankara ve İstanbul'da filmin galası yapılacaktır. Filmin çevrilmesinde görev almış olan şöhretler sahneye çıkacaktır. Hatta Ankara ve İstanbul'da yapılacak ilk gecelerin hasılatı, hükümetin göstereceği bir hayır kurumuna bağışlanacaktır. ${ }^{56}$

Aubrey Baring'in gazetecilere anlattıkları güzel planlardı. Ancak Atatürk filmi ile ilgili yapılması gerekli ilk şey bir hikâye yazmaktı. Bridget Boland'ın yazdığı öykünün tamamlandığı yönünde basında iki ay boyunca sürekli haberler çıkmıştır. ${ }^{57}$ Nihayetinde 25 Ocak 1955 tarihinde Adil Özkaptan, hikâyenin tamamlandığını, on beş gün sonra hikâyenin onaylanması için Cumhurbaşkanlığı Genel Sekreterliği'ne sunulacağını duyurmuştur. ${ }^{58}$

Gazetelere göre, Bridget Boland'ın iki farklı hikâye yazmasına rağmen filmin hikâyeleri beğenilmemiştir. Bu iş karşılığında 50.000 dolar (141.000 Türk Lirası) ödenmiştir. Yapımcılar, yeni bir hikâye yazması için yeni bir yazar aramaktadırlar. ${ }^{59}$ Basında daha evvel Atatürk filminin hikâyesini baştan yazmak üzere Anthony Veiller adında Amerikalı bir yazarın geleceği ve görüşmeler yapılacağı yazılmıştır. ${ }^{60}$ Anthony Veiller'in Türkiye'ye geldiğine dair herhangi bir bilgi bulunamamıştır.

53 Cumhuriyet Gazetesi, 23 Ağustos 1954, s.1.

54 Cumhuriyet Gazetesi, 5 Ekim 1954, s.1.

55 Cumhuriyet Gazetesi, 15 Ekim 1954, s.5.

56 Cumhuriyet Gazetesi, 5 Kasım 1954, s.6.

57 Milliyet Gazetesi, 10 Kasım 1954, s.3.

58 Cumhuriyet Gazetesi, 25 Ocak 1955, s.2.

59 Milliyet Gazetesi, 6 Temmuz 1955, s.1-7.

60 Milliyet Gazetesi, 22 Temmuz 1955, s.7; Dünya Gazetesi, 22 Temmuz 1955, s.2. 
Atatürk filminin hikâyesinin yabancı bir yazara ısmarlanması Türk basınında tepki çekmiştir. Bu tepki, yazara 50.000 dolar ödendiği haberlerinden sonra çıkması dikkat çekicidir. Cumhuriyet gazetesinde imzasız "Kendi Kendimizi Tenkit" köşesinde Atatürk filminin hikâyesini yazabilmek için "her şeyden evvel onu çok iyi bilmek, çok iyi anlamış olmak ve pek çok sevmek" gerektiği iddia edilmiştir. Yazara göre, elbette bu özellikler Türk yazarlarda mevcuttur. ${ }^{61}$ Milliyet gazetesinde "Doğrusu Bu" adlı köşede; "Atatürk'ün aziz hatırasının bu kadar devşirme ve uydurma bir şekilde ticaret mevzuu hâlinde kullanılmasına müsaade edilecek mi?" denilerek tepki gösterilmiştir. ${ }^{62}$ En sert tepki, Peyami Safa'dan gelmiştir. Safa'ya göre, birçok Türk aydınının Batı'ya karşı aşağılık duygusu içinde olduğunu, onlarda "yabantaparlık yani ecnebi hayranlığı" olduğunu yazmıştır. Cumhuriyet döneminde yabancılar tarafından yapılan heykelleri ve binaları züppe aydınların yabancı hayranlığının maskaraca tezahürü saymaktadır. Safa, makalesini şu sözlerle tamamlamaktadır:

“Bu yabantaparlık Türkiye' de kapitülâsyonlar devrinden kalma bir sömürge münevveri ruhunun devamıdır. Eğer Atatürk filmine de bu sefil zihniyet karışmışsa, onun hayatını yabancı muharrirlere yazdırmak ve filmdeki rolünü yabancı aktörlere oynatmak zıpırlığına hiddet edilir ama hayret edilir mi?" 63

Ancak herkes Peyami Safa ile aynı görüşte değildir. Refi Cevad Ulunay, tarihi Türk filmlerinde yapılan mizansen hatalarından örnekler vererek bu nesnelere film denilemeyeceğini yazmaktadır. O’na göre Türkiye'de Atatürk filmini çevirebilecek bir Türk yönetmen, senarist ve aktör mevcut değildir. ${ }^{64}$

Ünlü karikatürist Cemil Cahit Cem ise, Atatürk'ün yeni bir milli kahraman olması O’nu tanıyan herkesin hayatta olması nedeniyle Atatürkfilminin bir belgesel değil romanse hikâye olmasını büyük bir cüret ve cesaret işi olarak görmektedir. Cem, Atatürk'ün filmini rantabl yapmak için Amerikalıların Atatürk mevzuunu Robin Hood filmi haline getirebileceklerini; seyirci çekmesi için Atatürk filmini aşk ve macera filmine dönüştürebileceklerini yazmıştır. Atatürk filmini "tehlikeli bir iş" olarak gören Karikatürist Cem, kurmaca bir Atatürk filminin çekilmemesi gerektiğini düşünmektedir. Nedeni ise Cem'e göre, "Atatürk'ün bir milli kahramandan öte bir milletin hayatiyet ve hürriyet sembolü" olmasıdır. ${ }^{65}$

Atatürk ile ilgili ilk film projesi girişimi başarısız kalmıştır. Projenin akim kalmasının nedeni açıklanmasa da yazılan senaryonun beğenilmemesi nedeniyle projenin hayata geçmediği açıktır. İnce bıyık modasının yaratıcısının oğlundan Atatürk filminden hiçbir haber çıkmadığını belirten muhalif Akis dergisi, Atatürk'ün gayri ciddi bir elden kurtulduğu için derin bir "oh" çekmiştir. ${ }^{66}$ Bu ilk girişimden akılda modası geçmiş Amerikalı bir aktöre krallara layık bir hürmet gösterilmesi kalmıştır.

\section{İkinci Film Girişimi: “Universal Atatürk”}

1954 yılında başlayan ve 1955 yılında hüsranla sona eren Atatürk filmi girişiminin ardında Amerika'da yaşayan Adil Özkaptan vardı. Douglas Fairbanks Jr. ile Türkiye arasında Atatürk filmi için aracılık eden Özkaptan'dır. İlk girişimin başarısızlıkla sonuçlanmasının

61 Cumhuriyet Gazetesi, 8 Temmuz 1955, s.1.

62 Milliyet Gazetesi, 23 Temmuz 1955, s.1

63 Peyami Safa, "Bir Okuyucumuzun Haklı Asabiyeti," Objektif, Milliyet Gazetesi, 12 Temmuz 1955, s.2.

64 Refi Cevad Ulunay, "Mevcud Na Mevcud," Takvimden Bir Yaprak, Milliyet Gazetesi, 4 Aralık 1954, s.3.

65 Cemil Cahit Cem, "Atatürk Filmi Meselesi," Bana Sor, Milliyet Gazetesi, 22 Ekim 1955, s.3.

66 "Atatürk Filmi" Akis Dergisi, Sayı:93, 18 Şubat 1956, s. 24-25. 
ardından Adil Özkaptan 1955 yılı bitmeden Atatürk filmi için başka bir yapım şirketine teklif götürmüştür. Universal International Şirketi, Atatürk filmini çekmeye karar vermiştir.

4 Kasım 1955 günü Universal International Şirketi yetkilileri İstanbul'a gelmiştir. ${ }^{67}$ Prodüktör Aaron Rosenberg, senarist Borden Chase, teknik prodüktör Gilbert Cilaud ve yardımcısı İstanbul Hilton Oteli'nde basın toplantısı düzenlemiştir. Amerikalılar, Atatürk filmi basın toplantısında "Dünyanın en büyük insanlarından birinin hayatını filme almak üzere buradayız. Yegâne gayemiz ona layık bir film hazırlamaktır. Bu güzel memlekette, böyle değerli bir mevzuu filme çekecek ilk şahıslar olduğumuz için sevincimiz sonsuzdur." sözleri ile başlamışlar ve filmin senaryosunu yazacak olan Borden Chase, aylardan beri Atatürk ile ilgili kitaplar okuduğunu, okuduklarının kendisini bambaşka ve heyecanlı adam yaptığını anlatmıştır. Filmin kendisini "bir okul talebesi gibi heyecanlandırdığını" anlatan Chase, Atatürk için "gayesi olan adam" tabirini kullanmıştır. Film ekibi, Atatürk'ü övmeyi ihmal etmemiş, Chase, onun büyüklüğüne hayran kalırken, Prodüktör Aaron Rosenberg, kitap okudukça Atatürk'e daha fazla bağlanmıştır. Atatürk filminin senaryosu için Atatürk'ün yakın çevresinde bulunan İsmet İnönü, Ruşen Eşref, Makbule Atadan, Rauf Orbay ve Kılıç Ali gibi kişilerle görüşeceklerini ve filmin çekilmesi muhtemel şehirlerde inceleme yapacaklarını duyurmuşlardır. Araştırmanın ardından yazılacak senaryo Ankara'da ilgililerin onayına sunulacaktır. Çünkü film şirketi ile yapılan anlaşmaya göre senaryonun, yazılışı, filmin çevrilmesi ve oynatılması sırasında Türk hükümetinin müdahale hakkı bulunmaktadır. Atatürk filmi, Atatürk'ün okul hayatından başlanarak ölümüne kadar geçen süre başta Milli Mücadele olmak üzere bütün mücadeleleri, eserleri, zaferleri ile anlatılacaktır. Renkli çekilecek filmin tahmini maliyeti 10 Milyon Türk lirasını bulacaktı. Amerikalı Prodüktör Rosenberg, 1956 yılının Haziran ayında filmin çekilebileceğini söylemiştir. ${ }^{68}$

Amerikalılar, Atatürk'ün yakın çevresinde bulunan yazar Falih Rıfkı Atay ile görüşmüşlerdir. ${ }^{69}$ Falih Rıfkı Atay'a göre, Amerikalı film yapımcıları Atatürk ve Türkiye ile ilgili yabancı dilde yazılanları okumuşlar, Atatürk'e bir milli kahraman ve asrın büyük bir insanı olarak âşık olmuşlardı. Atay gözlemlerini şu şekilde anlatmaktadır:

"Ciddi bir eser yapmağa karar vermişlerdir. Sualleri pek etraflı idi, bilhassa kitaplarda bulunmayan hususiyetlerini öğrenmeğe ehemmiyet verdikleri anlaşllıyordu. Bunun sebebi de kolay anlaşılabilir. Ismarlama bir film değil, görenlerin anlayacağı, inanacağı, Atatürk'ü bir millî kahraman ve bir insan olarak tanıtır bir film yapmak istiyorlar. Amerikalı perde adamları her çeşit kitap okuyarak, birçok kimselerle konuşarak yazılanları ve anlatılanları emniyetli bir kontrol altına almaya çalışmaktadırlar. Eğer titizce dikkatlerinin ve tetkiklerinin mahsulünü vermeye muvaffak olurlarsa Atatürk filmi dünya ölçüsünde bir şöhret ve ehemmiyet olabilir ve bize umduğumuzdan daha çok hizmeti dokunabilir."

Ancak herkes Falih Rıfkı kadar filmden umutlu değildir. Film ile ilgili itiraz Mustafa Kemal Derneği'nden gelmiştir. Mustafa Kemal Derneği Başkanı Muhtar Kumral, Atatürk hakkında dört bin eser yazılmış olduğunu ve sadece bunların incelenmesi için uzun senelere ihtiyaç olduğunu söylemiştir. Atatürk filminin, İskender veya Napolyon filmi gibi macera filmi değil, dokümanter bir film olması lüzumunu belirten Dernek Başkanı;

67 Cumhuriyet Gazetesi, 5 Kasım 1955, s.3; Milliyet Gazetesi, 5 Kasım 1955, s.1; Dünya Gazetesi, 5 Kasım 1955, s.1.

68 Cumhuriyet Gazetesi, 6 Kasım 1955, s.1-7. Milliyet Gazetesi, 6 Kasım 1955, s.3; Vatan Gazetesi, 6 Kasım 1955, s.1-7; Akşam Gazetesi, 6 Kasım 1955, s.1.

69 Dünya Gazetesi, 8 Kasım 1955, s.2.

70 Cumhuriyet Gazetesi, 15 Kasım 1955, s.5 
filmin her bakımdan mükemmel olmasını isteyen halkın Derneğe belgeler gönderdiğini açıklamıştır. Bu belgeler ise, Atatürk'ün şahsî fotoğrafçısında bulunan 10 bin fotoğraf, İstiklal Harbi filmidir. Atatürk'ün uzun müddet emir subaylığını yapmış olan emekli bir subay da film için yardım edebileceğini söylemiştir. ${ }^{71}$

Atatürk filminin Türk prodüktörü Adil Özkaptan, düzenlediği basın toplantısında Mustafa Kemal Derneğinin iddiasına cevap vermiştir. Adil Özkaptan; "Bu dernek Atatürk filminin kâfi derecede dokümanteri olamayacağını iddia etmektedir. UniversalInternational Stüdyosu Atatürk hakkında dokümanter ve kronolojik bir film hazırlamak iddiasında değildir. Bizim gayemiz Atatürk'ün en az yüz milyon insan tarafından hayranlıkla seyredilecek bir hayat ve başarı hikâyesini en güzel bir şekilde canlandırmaya çalışmaktır" demiştir. $^{72}$

Amerikalı film yapımcıları Türkiye ziyaretlerinde özel uçakla Ankara'ya da gitmişler, Ankara'ya giderken İnönü Savaşları'nın geçtiği yerleri havadan incelemeyi de unutmamışlardır. Ankara'nın ardından Çanakkale'yi de ziyaret etmişlerdir. ${ }^{73}$ Amerikalı film yapımcıları Cumhurbaşkanı Celal Bayar, Türkiye Büyük Millet Meclisi Başkanı Refik Koraltan, Başbakan Adnan Menderes, bazı bakanlar, Ana muhalefet lideri İsmet İnönü ile görüşmüşler, Anıtkabir'i ve Çankaya Köşkü'nü ziyaret etmişlerdir. ${ }^{74}$ Akis dergisi, Ankara ziyaretlerinde Amerikalıların sarhoş olup Ankara Palas Oteli'nde küçük çaplı bir olay çıkarttıklarını yazmıştır. Oda arkadaşı horladığından şikâyet eden Amerikalının "zom" bir vaziyette otelin girişinde oturarak "parkta yatacağım" dediği iddia edilmiştir. ${ }^{75}$ Üst düzey bir protokol ve ilgi ile ağırlanan yapımcılar, Türkiye'deki incelemelerinden memnun kalmışlar, beyanlarına göre Atatürk hakkında tahminin üzerinde bilgi toplamışlardır. Başlangıçta 7-8 hafta Türkiye'de kalacaklarını söyleyen Amerikalılar, 16 gün süren ziyaretin ardından 21 Kasım 1955 günü Türkiye'den ayrılmışlardır. ${ }^{76}$ Amerikalıların üst düzey bir protokol ve ilgi ile ağırlanmasına Akis dergisi dışında genel olarak Türk basını tepki vermemiştir. Akis dergisi, Amerikalılara hükümdar muamelesi yapıldığını yazmıştır. Amerikalı film yapımcılarını "kendi sahalarında adları duyulmamış" isimler olarak niteleyen Akis dergisi, devlet katında gösterilen aşırı ilginin ancak şark hükümdarlarının idare ettikleri yerlerde gösterilebileceğini ifade etmiştir. ${ }^{77}$

Filmin daha sinopsisi bile ortada yok iken film yapımcıları Atatürk filmini, 100 milyon kişinin izleyeceğini hesaplamışlardır. Filmin prodüktörü Aaron Rosenberg, Atatürk filmini "Hollywood tarihinin en muhteşem prodüksiyonunu yapmaz isem futbol antrenörlügüne başlayacağım" diyecek kadar iddialıdır. ${ }^{78}$ Amerikalılar, Türkiye'den ayrıldıktan sonra da Türkiye'ye ilgilerini ve övgülerini iletmekten geri durmadılar. Senaryo yazarı Borden Chase, hasta yatağındaki Atatürk'ün kız kardeşi Makbule Atadan'a gönderdiği mektupta, "Dünyanın her tarafında fevkalâde insanlar tanımak mazhariyetine nail oldum. Sizin gölgeniz olabilecek birisini henüz görmedim. Sizinle geçirdiğim bir kaç saat zarfında cesaretin ne demek olduğunu ve Türkiye'nin haşmetini öğrendim"79 diye yazmıştır.

71 Milliyet Gazetesi, 9 Kasım 1955, s.3; Cumhuriyet Gazetesi, 20 Kasım 1955, s.2; Dünya Gazetesi, 9 Kasım 1955. 72 Cumhuriyet Gazetesi, 22 Kasım 1955, s.3; Dünya Gazetesi, 22 Kasım 1955, s:3.

73 Cumhuriyet Gazetesi, 15 Kasım 1955, s.5

74 Akis Dergisi, Sayı:81, 26 Kasım 1955, s.12; Vatan Gazetesi, 18 Kasım 1955,s.2; Cumhuriyet Gazetesi, 16 Kasım 1955 , s.5.

75 Akis Dergisi, Sayı:81, 26 Kasım 1955, s.12

76 Cumhuriyet Gazetesi, 18 Kasım 1955, s.3.

77 Akis Dergisi, Sayı:81, 26 Kasım 1955, s.12

78 Milliyet Gazetesi, 4 Aralık 1955, s.1-7; Dünya Gazetesi, 4 Aralık 1955, s.1-7.

79 Milliyet Gazetesi, 2 Ocak 1956, s.1-7 
Bir ay ABD'de kaldıktan sonra Türkiye'ye dönen Adil Özkaptan, 27 Ocak 1955 tarihinde Atatürk filmi ile ilgili gelişmeleri ve çalışma programını anlatmıştır. Senarist Borden Chase, Atatürk filminin hikâyesini tamamlamak üzere olduğunu, hikâyenin Mart başında Türkiye'ye gönderileceğini ve hükümet tarafından tespit edilecek bir jürinin onayına sunulacağını aktarmıştır. Mart sonunda Borden Chase, Türkiye'ye gelecek ve jürinin tavsiyeleri üzerine hikâye üzerinde son rötuşları yapacaktır. Nisan ayında, Türkiye'den Atatürk filminde çalışacak Türk teknik elemanlara Amerikalı uzmanlar, kurs verecektir. Yine Nisan ayında Atatürk filminde rol alacak Türk oyuncuların elemesi yapılacaktır. Atatürk filminde 11 'i Amerikalı, geriye kalanları da Türk olmak üzere 175 oyuncu rol alacaktır. Figüranlar bu rakamın dışındadır. Amerikalı oyunculardan 4 tanesi ile anlaşılmıştır. Atatürk filminin çekilmesine Haziran ayında başlanacak, çalışma 5 Ay devam edecektir. Adil Özkaptan, Atatürk filminin 1957 senesinde tamamlanacağını sözlerine eklemiştir. ${ }^{80}$

Ancak bu çalışma takvimi daha sonra sürekli olarak ertelenecek ve yenilenecektir. Adil Özkaptan 16 Ağustos 1957 günü gazetecilere bu defa yeni bir çalışma takvimi sunmuştur. Borden Chase tarafından hazırlanan senaryo tasarısı, Amerika'dan nihayet gelmiştir. İngilizce olarak kaleme alınan 460 sahifelik senaryo tasarısı, derhal Türkçeye tercüme edilecek ve Atatürk'ün yakın arkadaşlarına dağıtılacak, fikirleri sorulacaktır. İç ve dış sahneleri tamamı ile Türkiye'de ve olayların geçtiği yerlerde çekilecektir. Filmde görev alacak Türk teknisyenler ve sanatçılara Amerika'dan gelecek bir heyet tarafından kurs verilecektir. Filmde, figüranlar hariç, 200 artist rol alacaktır. Atatürk'ün filmi, 6 milyon dolara mal olacak, çekimi 6 ay sürecektir. Film, 1959 senesinden önce, vizyona giremeyecektir. Filmin çekimine ancak Türk hükümetinin senaryonun nihai şeklini onaylanmasından sonra başlanabilecektir. ${ }^{81}$

Filmin çekim takviminin ertelenmesinin nedeni Türk yetkililerinin senaryoyu onaylamamasıdır. Senaryo ile ilgili pürüzler vardı. Devreye Universal International Film Şirketi'nin Genel Müdürü Alfred Daff girmiştir. Filmle ilgili çıkan pürüzleri çözmek için 5 Eylül 1956 'da Türkiye'ye gelmiştir. Daff, Atatürk filminin şimdiye kadar yaptıkları en iyi film olacağını iddia etmiştir. Bir hafta süren ziyaretinde Cumhurbaşkanı Celal Bayar ile görüşmüştür. Bayar, görüşmede "Atatürk filmini 24 milyon Türk'ten başka dünyanın yarısının ve henüz onu tanımayanların da heyecanla beklediğini" söylemiştir. Daff, Atatürk'ün yakın arkadaşları ile de görüşmüştür. Düzenlediği basın toplantısında film ile ilgili çıkan pürüzlerden bahsetmemiş ancak Türkiye'nin yeterince tanıtımının yapılmadığından söz ederek Türk yetkililere mesaj göndermiştir. Daff, Türkiye'nin kendisini dışarıda tanıtmaması yüzünden her sene kaçırdığı Amerikan turistlerinden bahsederek "Bu sene Avrupa'ya gelen 1.300.600 Amerikan turistinin acaba kaçı bu güzel memlekete gelmiştir? Bu güzelliği tanıtmamakla yazık ediyorsunuz" demiştir. Daff, Atatürk filmine 1957 yılının Mayıs ayında başlanması ihtimali olduğunu ve filmin 3,5 seneden evvel bitmeyeceğini de ifade etmiştir. ${ }^{82}$

\section{Universal’e Fransız Rakip}

Adil Özkaptan'ın iddiasına göre, Amerika'da herkes Atatürk filminin çevrilmesi ile ilgilidir. 7 büyük film şirketi, Universal ile rekabete girişmiştir. Film çevirme hakkına sahip

80 Cumhuriyet Gazetesi, 28 Ocak 1956, s.3; Milliyet Gazetesi, 28 Ocak 1956, s. 7; Dünya Gazetesi, 28 Ocak 1956, s.3.

81 Cumhuriyet Gazetesi, 17 Ağustos 1956, s.5; Dünya Gazetesi, 17 Ağustos 1956, s. 3; Vatan Gazetesi, 17 Ağustos 1956 , s.5.

82 Cumhuriyet Gazetesi, 13 Eylül 1956, s.1;Dünya Gazetesi, 13 Eylül 1956, s.1-3; Vatan Gazetesi, 6 Eylül 1956, s. 1-3. 
olabilmek için ciddi teklifler yapılmıştır. ${ }^{83}$ Amerika'daki durumu bilemekse de Universal'e bir rakip Fransa'dan çıkmıştır. Yaşanan senaryo pürüzü, Avrupalı sinemacıların da dikkatini Atatürk filmine çekmiştir. Türklerin Amerikalılara sunduğu fırsat ve bütçenin Atatürk filmine dikkatlerin çekilmesinde önemli bir faktör olduğu unutulmamalıdır. Ünlü Fransız yönetmen Christian Jaque, Atatürk filmine hazırlandığını Türk basınına duyurmuştur. Christian Jaque, senaryonun mutlaka Türk bir yazar tarafından yazılmasını birinci şart olarak ileri sürmüştür. Yönetmen, herhangi yabancı yazara göre bir Türk yazarının Atatürk'ü daha bilerek ve daha derinden anlayarak yazacağına emindir. ${ }^{84}$ Açıklamanın zamanlaması, senaryo problemi yaşayan Türk yetkililere Christian Jaque'ın alternatif bir yöntem sunduğunu akla getirmektedir. Fransız yönetmen, Amerikalıların yaşadığı problemi Türk bir yazarla aşabileceğini zannetmektedir. Oysa yaşanan problem, senaryo yazarının milliyetinden değil Türk yetkililerin Atatürk filmine dar ve sığ bakış açılarından kaynaklanmaktadır. Jaque, Atatürk filmi için yeni bir pazar da keşfetmiştir. Güney Amerikalıların kahramanları Simon Bolivar ile karşılaştıracakları için Atatürk filmine ilgi göstereceklerdir. Atatürk rolü belli olmasa da Latife Hanım rolü çoktan dönemin ünlü Fransız oyuncusu ve Christian Jaque'ın eşi Martine Carol'a verilmiştir. ${ }^{85}$

\section{Atatürk Rolü İçin Uzun Aday Listesi}

Amerikalı yapımcılar ve Türk yetkiler arasında senaryo krizi yaşanırken, Türk basını senaryodan ziyade Atatürk rolünü hangi aktörün canlandıracağı ile daha çok ilgilenmiştir. Projenin en başında Atatürk rolü için erkek oyuncu adayları Laurence Olivier, John Wayne, Marlon Brando olarak sayılmaktadır. Bu üç ünlü aktörle deneme çekimi yapılacağı iddia edilmiştir. ${ }^{86}$ Kadın oyuncunun ise Audrey Hepburn olması istenmektedir. Ama o da net değildir. ${ }^{87}$ Adil Özkaptan, Mart 1956 'da Atatürk rolünü Yul Brynner'in oynayacağını açıklamıştır. Burt Lancester da Atatürk rolüne talip olmuş kendisi ile bir deneme çekimi yapılmasını istemiştir. O zamana kadar dönemin ünlü oyuncularının isimleri ileri sürüldüğü için Türk basını, Türkiye'de henüz tanınmayan Yul Brynner ismini sürpriz olarak nitelendirmiştir. ${ }^{88}$ Çünkü Yul Brynner, o tarihte çiçeği burnunda yeni bir oyuncudur. Broodway'de bilinir bir kariyeri olsa da o tarihte sinemada ünlü bir oyuncu değildir. Ancak 1956 yılında oynadığı "Kral ve Ben” filmi ona uluslararası bir şöhret ile birlikte En İyi Erkek Oyuncu Oscar'ını getirmiştir. Yul Brynner açıklamasından beş ay sonra Adil Özkaptan bu defa Atatürk rolünü aktörün 350.000 dolar alacağını açıklamıştır. Ancak bu defa da aktörün ismini vermemiştir. ${ }^{89}$ Eylül 1956 'da, Universal Genel Müdürü Alfred Daff, Atatürk rolünü oynayacak aktörün henüz belli olmadığını söylemiştir. ${ }^{90}$ Hollywood ziyaretinde Ahmet Emin Yalman, Atatürk rolünün Yul Brynerr'a verilmesinde herkesin müttefik olduğunu ancak Clark Gable, Kirk Douglas, Laurence Olivier'in muhtemel diğer adaylar olduğunu yazmıştır. Atatürk'e çok benzediğini düşünen Denizcilik Bankası Gümrük Uzmanı Remzi Cal, Yalman'dan Atatürk rolünün kendisine verilmesi için aracılık yapmasını istemiştir.

83 Milliyet Gazetesi, 28 Ocak 1956, s.1

84 Milliyet Gazetesi, 30 Mayıs 1956, s.3; Cumhuriyet Gazetesi, 16 Ekim 1956. s..3; Vatan Gazetesi, 16 Ekim 1956, s.1.

85 Dünya Gazetesi, 30 Mayıs 1956, s.3-5; Vatan Gazetesi, 30 Mayıs 1956, s.2; Tarık Kakınç, "Sinema Notları," Pazar Postası, 10 Haziran 1956, s.8-11.

86 Cumhuriyet Gazetesi, 6 Kasım 1955, s..1.; Milliyet Gazetesi, 6 Kasım 1955; Milliyet Gazetesi, 4 Aralık 1955 ,s.1; Dünya Gazetesi, 4 Aralık 1955,s.7.

87 Dünya Gazetesi, 22 Kasım 1955, s.3.

88 Cumhuriyet Gazetesi, 20 Mart 1956, s..5; Milliyet Gazetesi, 20 Mart 1956, s.3;Dünya Gazetesi, 20 Mart 1956, s.1-5.

89 Cumhuriyet Gazetesi, 17 Ağustos 1956. s..5; Dünya Gazetesi, 17 Ağustos 1956, s.3, Vatan Gazetesi 17 Ağustos 1956 , s.5.

90 Milliyet Gazetesi, 6 Eylül 1956, s.3; Akşam Gazetesi, 6 Eylül 1956, s.1. 
Ancak bu amatör benzerin isteği film yapımcıları tarafından reddedilmiştir. ${ }^{91}$ Filmle ilgili yapılan son açıklamada, Atatürk rolünü canlandıracak Amerikalı oyuncu ile 1957 yılının ilk günlerinde sözleşme imzalanacağı duyurulmuştur. Ancak yıldızın ismi açıklanmamıştır. ${ }^{92}$

Atatürk'ü hangi aktörün canlandıracağı meselesi ilk günden itibaren Türk basını için eğlenceli bir malzeme olmuştur. Türk gazeteciler her rastladıkları Hollywood ünlüsüne Atatürk filmini sormuşlar ve Atatürk rolünü teklif etmişlerdir. Ünlü aktör Gary Cooper, o aktörlerden biridir. Cooper, Atatürk rolünü memnuniyetle kabul edeceğini söylemiş ancak Atatürk filmini çekmenin "son derece güç bir iş" olarak tarif etmiştir. Çünkü Cooper’a göre, Atatürk yalnızca kendi memleketine değil bütün dünyaya büyük eserler kazandıran bir insandır. ${ }^{93}$ Macera filmlerinin aranan karizmatik oyuncusu Errol Flyn ise, Atatürk'ü "20. asrın en büyük devlet adamı" olarak övmüştür. Flyn, Atatürk rolünü hakkıyla oynayamayacağından endişe etmektedir. ${ }^{94}$ Dönemin bir başka ünlü aktörü Glenn Ford, Atatürk'ü tarihin en büyük adamlarından biri olarak övdükten sonra, Atatürk rolünün kendisi için büyük şeref olacağını ancak başka film sözleşmeleri olduğunu söylemiştir. ${ }^{95}$ Türk basınına Atatürk'ü övmeyi inmal etmeyen Hollywood ünlüleri, Atatürk rolü için çekincelerini kibar bir dille belirtmişlerdir.

\section{Kovboycu Chase- Fakir Universal- Mutavassıt Özkaptan}

1950 ve 1960 'lı yıllarındaki tüm Atatürk filmi projelerinin içinde hep Adil Özkaptan ismi olmuştur. Douglas Fairbanks Jr.'ın Türkiye ziyaretinin ardında Adil Özkaptan vardı. Douglas Fairbanks Jr. ile Atatürk'ün hayatı ile ilgili film yapma teklifini yapmıştır. Atatürk filmi projesi, Cumhurbaşkanı Celal Bayar ile Fairbanks, arasında aracılık etmiştir.

Universal Şirketinin Atatürk filmi projesinde de Adil Özkaptan vardı. Basın toplantıları düzenlemekte, gazetecilere Atatürk filmi hakkında bilgiler vermektedir. Kendisini Atatürk filminin Türk sermayedarı ve prodüktörü olarak tanıtmıştır. Adil Özkaptan için kimi gazete ve dergiler ise "Türk sinema seyircilerinin ismini bir türlü hatırlayamadığı bir zat," "96 "ne prodüktörü olduğu pek anlaşılamayan kişi" gibi alaycı ifadeler kullanmışlardır. Hakikaten kendisini prodüktör olarak tanıtmasına karşın Adil Özkaptan'ın ne o tarihe kadar ne de o tarihten sonra herhangi bir filmin prodüktörlüğünü yaptığı görülmemiştir. Adil Özkaptan'ın Atatürk filmindeki rolünü en doğru şekilde Ahmet Emin Yalman tanımlamıştır. Hollywood'da film yetkileri ile görüşen Yalman, Adil Özkaptan'ın Atatürk filminde "mutavassıt"(aracılık eden) görevini gördüğünü yazmaktadır. ${ }^{98}$

Türk basınında genel olarak Amerikalıların ticari kazanç hevesi ile Atatürk filminin aşk ve macera filmine dönüştürecekleri endişesi hâkimdir. Cumhuriyet gazetesinin "Kendi Kendimizi Tenkit" başlıklı imzasız köşesinde bir hafta zarfında yapılacak dört, beş mülakat ile senaristin Atatürk'ü anladığını zannedeceğini oysa Türk vatandaşları arasında bile Atatürk'ü tam manası ile anlamış çok az kişinin olduğu yazılmaktadır. Yazı, "Amerikalılar hiç şüphesiz bir film yapacaklar, bu film belki güzel de olacak. Fakat katiyen

91 Ahmet Emin Yalman, "Atatürk Filminde Başrolü Kim Oynayacak? " Yalman Hollywood'da-11, Vatan Gazetesi, 26 Haziran 1957, s.4.

92 Cumhuriyet Gazetesi, 27 Aralık 1956. s..5.

93 Milliyet Gazetesi, 10 Haziran 1956, s.1; Vatan Gazetesi, 10 Haziran 1956, s. 1-5; Akşam Gazetesi, 10 Haziran 1956, s.1.

94 Milliyet Gazetesi, 6 Nisan 1956, s.3.

95 Ahmet Emin Yalman,"Glenn Ford," Yalman Hollywood'da-15, Vatan Gazetesi, 30 Haziran 1957, s.4.

96 "Atatürk Filmi" Akis Dergisi, Sayı:93, 18 Şubat 1956, s. 24-25.

97 Tarık Kakınç, "Sinema Notları," Pazar Postası, 10 Haziran 1956, s.8-11.

98 Ahmet Emin Yalman," Atatürk Filmi," Yalman Amerika'dan Yazıyor-11, Vatan Gazetesi, 20 Mayıs 1958, s.2. 
Atatürk'ün filmi olmayacak" şeklinde sona ermektedir. ${ }^{99}$ Milliyet gazetesinde ise yine imzasız "Doğrusu Bu" köşesinde Atatürk filmi işinde kazanç peşinde koşanların ciddi bir araştırmadan uzak kaldıklarını bu yüzden Atatürk filminde bazı "yakışıksızlıkların" olacağı iddia edilmektedir. Köşede, Atatürk filmi "nazik ve tehlikeli" bir iş sayılarak hükümetin kontrolü gevşek bırakmaması salık verilmiştir. ${ }^{100}$ Benzer endişeleri sokaktaki vatandaş da paylaşmaktadır. Gazeteci Ümit Deniz, sokaktaki adamın Atatürk filmi ile ne düşündüğünü araştırmıştır. Vatandaşların bir kısmı Amerikalıların Türkleri ve Atatürk'ü anlamayacaklarını, Atatürk'ü hiçbir aktörün canlandıramayacağına inandıkları için Atatürk filmine karşı çıkmışlardır. Atatürk filminin çevrilmesine destek olanlar filmin Türkiye'nin tanıtımına ve propagandasına katkısı olacağını düşünmektedirler. ${ }^{101}$ Akis dergisi, Atatürk filminin tüm dünyada ilgi çekebilmesi için "muhteris" film yapımcılarının Atatürk filmine "malûm ortak ölçüler olan aşk, heyecan ve macera" katacaklarını, Atatürk filminin ticari bir meta haline dönüştürülmesine engel olunması gerektiğini yazmıştır. ${ }^{102} \mathrm{Akşam}$ gazetesinde Cemal Refik ise Atatürk filmine tamamen karşıdır. "Cihana parmak ısırtan bir dehâ kudretinin askerlik, politikacılık, idarecilik, inkılâpçılık, irfan, irşat sahalarında bin bir çeşit başarı eserleriyle tıklım tıklım dolu olan bu ummanın sinema şeridine sıkıştırılmasının" mümkün olmadığını iddia etmektedir. ${ }^{103}$ Atatürk filminin "yılan hikâyesine" döndüğünü söyleyen Tarık Dursun Kakınç, Hollywood'un bir büyük adamın hayat hikâyesini perdeye yansıtmak yerine, adından faydalanarak filmi daha çok iş yapar hale getirmek için çalıştığını yazmıştır. Senaryosunu John Steinbeck'in yazdığı, yönetmenliğini Elia Kazan'ın yaptığı "Viva Zapata” filmini örnek veren Kakınç’a göre, film, kusursuz ve başarılıdır ancak filmden akılda Zapata'nın halkı için harcadı̆̆ı güç ve çaba değil, Marlon Brando'nun ve Jean Peters'in aşk sahneleri kalmıştır. Kakınç, "Ulusça kutlu bir kişi olan Atatürk'ün; aşağı yukarı bir Zapata olarak" çıkabileceğinden korkmaktadır. ${ }^{104}$ Pazar Postası Dergisinin bir başka yazarına göre, Amerikalılar başka milletlerin büyükleri için çevirdikleri filmlerde bu kahramanları kafalarında düşündükleri gibi temsil ettiklerini ve bu kahramanlara "Amerikanlık" bulaşmaktadır. Atatürk'e "Amerikanlık" bulaşmasından endişe eden yazar, Atatürk filminden vazgeçilmesi gerektiğini yazmaktadır. Çünkü O’na göre, “Atatürk'ün propagandaya ihtiyacı yoktur. "105 Universal Şirketi, gazeteci Ahmet Emin Yalman aracılığı ile bu iddialara yanıt vermiştir. Amerika'da yapımcılar ile görüşen Yalman'a göre; Amerikalıların filmi yapma amacı, "Atatürk'ün büyüklüğünü belirtmek, Türklüğün büyük davalarını bütün âleme aksettirmekti."106

Türk basınında film ile ilgili itirazlar, yalnızca içerik ile sınırlı kalmamıştır. Filmin yapımcılarının ve senaristinin de yetersiz olduğu yönünde eleştiriler de yazılmıştır. Bu eleştirilere göre, Aaron Rosenberg ve Borden Chase'in vasat kovboy filmleri çeviren Atatürk filmi için güven vermekten uzak isimlerdir. Akis dergisi, Türklerde senarist olmadığı için Türkler tarafından yazılan Atatürk filminin hikâyesinin bir Amerikalı senarist tarafından yazılmasını önermektedir. Ancak dergiye göre, bahsedilen Amerikalı senarist Borden Chase gibi bir "kovboycu" olmamalıdır. Universal International bünyesinde yetenekli bir yönetmen olmadığını iddia eden Akis Dergisi, usta yönetmenlerin Borden Chase ve Aaron Rosenberg ile çalışmayacaklarını, Atatürk filmi için stüdyo, prodüktör ve senaristin en 99 Cumhuriyet Gazetesi, 6 Kasım 1955, s.1.

100 Milliyet Gazetesi, 14 Kasım 1955, s.1

101 Ümit Deniz, "Atatürk Filmi Hakkında Halkımız Ne Düşünüyor," Milliyet Gazetesi, 8 Kasım 1955, s.3.

102 "Atatürk Filmi" Akis Dergisi, Sayı:93, 18 Şubat 1956, s. 24-25.

103 Cemal Refik, "Atatürk Filmi," İstanbul Hayat, Akşam Gazetesi, 6 Aralık 1955, s.3

104 Tarık Dursun Kakınç, "Yılan Hikayesi Atatürk Filmi" Pazar Postası, 10 Kasım 1957, s.3.

105 C.G., "Atatürk Filmini biz çevirmeliyiz" Pazar Postası, 10 Kasım 1957, s.3.

106 Ahmet Emin Yalman, “Atatürk Filmi Mutlaka Yapılmalı," Yalman Hollywood'da-10, Vatan Gazetesi, 25 Haziran 1957, s.4. 
ucuz takımından seçildiğini yazmıştır. Borden Chase ve Aaron Rosenberg, Atatürk filmiyle olmayan dehalarını ortaya koyamayacaklarını, onların bir iş adamı sıfatıyla yaptıklarının ücretlerini ceplerine indireceklerini ve Türklerin payına "Atam sana bu mu lâyıktı?" deyip üzülmek düşeceğini iddia etmiştir. ${ }^{107}$ Sinema eleştirmeni Tarık Dursun Kakınç da Borden Chase ve Aaron Rosenberg ekibinin ikinci sınıf western filmlerinin ekibi olduğunu yazmıştır. O'na göre; Atatürk filmini üstlenen isimlerin her birinin sıradan ve "baremli" birer sinema oyun yazarı, prodüktör ve rejisördür. Kakınç’a göre, Aaron Rosenberg ekibine teslim etmektense, Atatürk filminin çevrilmemesi daha iyidir. ${ }^{108}$ "Kovboycu Borden Chase" eleştirilerine karşılık ünlü gazeteci Ahmet Emin Yalman, Borden Chase'i öven yazılar yazmıştır. Anılarında 1957 baharında Hollywood seyahatinde hoş vakitler geçirdiğini yazan ${ }^{109}$ Ahmet Emin Yalman, bu seyahatindeki izlenimlerini Vatan gazetesinde tefrika şeklinde yayınlamıştır. Yalman, bu seyahatinde Atatürk filminin senaristi Borden Chase ile tanışmış ve evine konuk olmuştur. Yalman'a göre, Chase, "Atatürk'e dair yalnız bir senaryo yazmakla kalmamış, ona en derin bir sevgi ve anlayışla bağlı doğrudan doğruya aşık" olmuştur. ${ }^{110}$ Yalman, Chase'in fabrikalarda ve Hudson nehrinin altından geçen tünel inşaatında çalışarak zor bir hayattan geldiğini, eğitim imkânı bulamamasına rağmen diplomalarını hayatın sert mektebinden aldığını yazmaktadır. Chase'in yaşam öyküsünü aktaran Yalman'a göre, film senaryosu yazmak sanatında Chase birinci isimdir. Yalman'a göre, Amerikalı yazar Borden Chase'de "iyi bir Türk köylüsünün ve Mehmetçiğin saf temiz ruhu" vardır. Chase'e göre, "Atatürk bütün tarihin en büyük adamıdır, rekor teşkil edecek zorlukların altından kalkmış, dünyanın en çetin bir sahasında yaşayan bir milletin muhakkak bir ölümden kurtulmasına ve kısa zamanda geniş merhaleler aşmasına rehberlik etmiştir." Chase, Atatürk filminin senaristliğini hayatının en büyük fırsatı ve nimeti olarak kabul etmektedir. ${ }^{111}$ Yalman, Chase'i hak etmediği şekilde öven sözlerine 1958 yılında bir başka yazı ile daha devam etmiştir. Yine bir Amerika seyahati sırasında Borden Chase ile karşılaşan Yalman, Chase'i "Atatürk filmini hazırlamak üzere senelerce çalışan, memleketimizi defalarla ziyarete gelen yaman adam" olarak tarif etmektedir. Oysa Chase, Türkiye'ye defalarca değil yalnızca bir kez ve on beş günlüğüne gelmişti. Yalman, Chase'in Atatürk'e ve Türkiye'ye derin sevgiyle bağlı olduğunu tekrar etmektedir. Ancak Yalman, Chase'e övgüyü ve Chase'in Atatürk'e karşı sevgisini o denli abartır ki "Hepimiz Atatürk'ü sevmek iddiasında bulunabiliriz, fakat ona Bordon Chase kadar imanla bağlı olanlar, yaptıklarının manasını onun kadar kavrayanlar bizim aramızda bile çok sayılmaz" diye yazmaktadır. Ahmet Emin Yalman, ayrıca Borden Chase'in Atatürk filminin senaryosuna karşılık 150.000 dolar aldığını da yazmaktadır. ${ }^{112}$ Chase'in Atatürk'e karşı bu büyük aşkının ve bağlığının nedeni aldığı yüksek ücret mi bilinmez ama Yalman'ın sınırları zorlayan övgülerine Pazar Postası Dergisinden Tarık Kakınç tepki göstermiştir. Kakınç, Yalman'ın Chase'i kıskanılır bir dostlukla övdüğünü, göklere çıkarttığını, işi çığırından çıkarttığını yazmaktadır. Yalman'ın övdüğü Chase'in hiçbir yenilik getirmeyen kovboy filmlerinin yazarı olduğunu, Fransız eleştirmecilerinin alaycı bir şekilde Bordon Chase'i, vahşi Batının Homer'i olarak adlandırdıklarını yazmaktadır. ${ }^{113}$

107 Atatürk Filmi" Akis Dergisi, Sayı:93, 18 Şubat 1956, s. 24-25.

108 Tarık Dursun Kakınç, "Yılan Hikayesi Atatürk Filmi" Pazar Postası, 10 Kasım 1957, s.3.

109 Ahmet Emin Yalman, Yakın Tarihte Gördüklerim ve Geçirdiklerim 1922-1971 2. Cilt, Pera Turizm, İstanbul, 1997, s.1656.

110 Ahmet Emin Yalman, "Atatürk Filmi Müşaviri Vesamet Hanımla Buluşma" Yalman Hollywood'da-8, Vatan Gazetesi, 25 Haziran 1957, s.4.

111 Ahmet Emin Yalman, "Atatürk filminin senaryosunu yazan Chase'in evinde," Yalman Hollywood'da-9, Vatan Gazetesi, 25 Haziran 1957, s.4.

112 Ahmet Emin Yalman," Atatürk Filmi," Yalman Amerika'dan Yazıyor-11, Vatan Gazetesi, 20 Mayıs 1958, s.2. 113 Tarık Kakınç, "Atatürk Filminin Tuzu Biberi” Pazar Postası, 6 Temmuz 1958, s.13. 
Muhalif Akis dergisi ise, Atatürk filmi eleştirilerinin hedefine yapım şirketini de almıştır. Dergiye göre, Universal International Şirketi'nin birkaç defa iflasın eşiğine gelmiş, Amerika'nın en küçük ve en fakir film şirketlerinden biridir. Universal'n Atatürk filmi için havaya atılacak parası yoktur. Dergi, "sadece kovboy ve gangster filmleri çevirerek kıt kanaat geçinen bu şirketi biz mi kalkındıracağız?" diye sormaktadır. ${ }^{114}$ Hakikaten 1950 'li yıllarda Hollywood'a egemen olan Metro-Goldwyn-Mayer, Warner Bros, Paramount, Fox, R. K. O. Şirketlerinin oluşturduğu "Beş Büyükler" arasında Universal İnternational yoktur. Universal İnternational, Colombia, United Artists ile birlikte o yıllarda "Üç Küçükler" olarak adlandırılmaktadır. ${ }^{115}$ Universal International Film Şirketinin Genel Müdürü Alfred Daff, Türkiye ziyaretinde Türk basınında Universal'in küçük bir şirket olduğunu iddialarına Universal'in 1955 yılında 24 film çevirdiğini ve cirosunun 78 milyon doları bulduğunu söyleyerek karşılık vermiştir. ${ }^{116}$

\section{Dışişleri Bakanının Metresi, Atatürk Filminin Danışmanı}

Ahmet Emin Yalman, 1957 yılında Hollywood seyahatinde, Atatürk filminin müşaviri (danışman) Vesamet Kutlu ile karşılaştı̆̆ını yazmaktadır. Ahmet Emin Yalman, Vesamet Kutlu aracılığı ile senarist Borden Chase'in evine gitmiş ve filmin prodüktörü ve yönetmeni Rosenberg ile tanışmıştır. Yalman, Vesamet Kutlu'yu yıllar önce Washington'da elçilik kâtiplerinden birinin eşi olarak tanımıştır. O tarihte, Amerika gibi güzeli bol bir ülkede Vesamet Kutlu'nun ince ve zarif cazibesiyle dikkat çektiğini, bir süre sonra anne olduğunu daha sonra ise eşinden boşandığını yazmaktadır. Yalman, Vesamet Kutlu'nun Atatürk filmi danışmanlığı işini "Demek ki şimdi de Amerika'ya gelmiş, bir iş sahibi olmuş, yeni bir hayata girmiş" diyerek geçiştirmiştir. ${ }^{117}$ Vesamet Kutlu'nun Atatürk filmindeki danışmanlık görevi, kâğıt üstünde bir danışmanlık da değildir. Yalman'ın aktardığına göre, Universal Stüdyolarında bir bürosu ve sekreteri de vardır. Her sabah herkes gibi işinin başında bulunmaktadır. İşe gidip gelebilmek için otomobil dahi satın almıştır. Yalman, "bütün hayatını bir diplomatın eşi olarak geçiren genç kadının" Hollywood'a uyumuna ve rahatlığına hayran kalmıştır. ${ }^{118}$ Ancak Yalman, "bütün hayatını bir diplomatın eşi olarak geçiren genç kadının" hangi donanım ve yeterlilikle Atatürk filminin danışmanı yapıldığı meselesine hiç değinmemiştir.

Vesamet Kutlu, Ahmet Emin Yalman'ın da muhtemelen bildiği ancak değinmediği bir aşkın kahramanıdır. Dönemin Dışişleri Bakanı Fatin Rüştü Zorlu ile Vesamet Kutlu çok da "sır" olmayan bir aşk ilişkisi yaşamaktadır. Vesamet Kutlu, henüz on yedi yaşında iken Dışişleri Bakanlığında görevli Orhan Kutlu ile evlenmiştir. 1937-1945 yılları arası kocasının görevi nedeniyle Amerika'da kalmıştır. Vesamet Kutlu ile Fatin Rüştü Zorlu 1945 yılında tanışmışlar, ilişkileri ise 1947 yılında başlamıştır. Fatin Rüştü Zorlu da Emel Zorlu ile evlidir. İki evli çiftin yasak aşkı, Fatin Rüştü Zorlu'nun idam edildiği 1961 yılına dek sürmüştür. Vesamet Kutlu, 1954-55 yılında kocasından boşanmıştır. Fatin Rüştü Zorlu da Emel Zorlu'dan ayrılmak istemiş ancak özellikle annesinin karşı çıkmasıyla ayrılamamıştır. Emel Zorlu, bu ilişkiden haberdardır. 1956 yılından itibaren Vesamet Kutlu yurtdışında yaşamaya başlamıştır. Genellikle Paris ve İsviçre'de buluşan çift, beraberliklerini saklama

114 Atatürk Filmi” Akis Dergisi, Sayı:93, 18 Şubat 1956, s. 24-25; "İstanbul filmi çevrilirken,” Akis Dergisi, Sayı:96, 10 Mart 1956, s:37.

115 N Özer, Amerikan Sinemacılı̆ında Buhran" Yağmur ve Toprak, Sayı:26, Ocak 1951, s.25.

116 Cumhuriyet Gazetesi, 13 Eylül 1956, s.1;Dünya Gazetesi, 13 Eylül 1956, s.1-3; Vatan Gazetesi, 6 Eylül 1956, s. 1-3.

117 Ahmet Emin Yalman, “Atatürk Filmi Müşaviri Vesamet Hanımla Buluşma” Yalman Hollywood’da-8, Vatan Gazetesi, 25 Haziran 1957, s.4.

118 Ahmet Emin Yalman,"Glenn Ford," Yalman Hollywood'da-15, Vatan Gazetesi, 30 Haziran 1957, s.4. 
ihtiyacı duymamışlardır. Dışş̧leri Bakanı olan Zorlu, diplomatik toplantılara, balolara Vesamet Kutlu ile katılmıştır. O’nu kimi zaman "karısı" olarak tanıtmıştır. Yaşanan ilişkiden ailenin yanı sıra siyasi ve bürokratik çevrenin de haberi vardır. ${ }^{119} 27$ Mayıs askeri darbesinin ardından darbeciler, bu ilişkiyi ifşa etmişlerdir. Aranan evlerin arasında Vesamet Kutlu'nun Ankara'daki evi de vardır. Akis dergisi, çiftin baş başa resimlerine, ithaflı fotoğraflarına ve birbirinden hisli aşk mektuplarına el konulduğunu yazmıştır. ${ }^{120}$ Yasak aşk, Fatin Rüştü Zorlu'nun idam edilmesi ile hüzünlü bir şekilde sona ermiştir. Zorlu, idama giderken bile Vesamet Kutlu'yu düşünmüştür. Ailesine yazdığı son mektupta, Vesamet Kutlu'yu kastederek "Benim sevdiklerimi siz de sevin" diye yazmıştır. Fatin Rüştü Zorlu'nun evlilik dışı ilişkisine baştan beri karşı çıkan annesi Güzide Zorlu, oğlunun bu sözlerini vasiyet sayarak gelini Emel Hanım ölümünden sonra 1965 yılında Vesamet Kutlu ile tanışmıştır. Güzide Zorlu, öldüğü 1978 yılına kadar yazları Vesamet Kutlu ile birlikte yaşamış ve O’nu "gelinim" diyerek bağrına basmıştır. Vesamet Kutlu, yaşanan trajik olayların ardından Zorlu ailesi tarafından kabul edilmiştir. Fatin Rüştü Zorlu'nun kızı Sevin Zorlu O’nu "üvey annesi" olarak görmüştür. Vesamet Kutlu ise 1998 yılındaki ölümüne kadar yasak aşkını içinde yaşatmış ve Fatin Rüştü Zorlu'ya bağlığını sürdürmüştür. ${ }^{121}$ Fatin Rüştü Zorlu-Vesamet Kutlu'nun yasak ilişkisi, sonu trajedi ile biten gerçek ve büyük bir aşk olarak tarihe geçmiştir.

Atatürk filminin danışmanı olan Vesamet Kutlu böyle bir öykünün kahramanıdır. Atatürk filminin danışmanlığı işinde mutlaka Zorlu'nun rolü olmalıdır. Muhtemeldir ki, Türk Hükümetinin güçlü adamına şirin görünmek için Universal Şirketi, Bakanın metresini Atatürk filmine danışman yapmış olabilir. Tanıyan herkesin "bilgili, kültürlü ve hoş bir hanım" olarak tarif ettikleri ancak lise mezunu dahi olmayan Vesamet Kutlu, kuşkusuz Atatürk filmi gibi tarihi bir konuya danışmanlık yapacak vasıflara sahip değildir.

\section{Filmin Finansmanı Bilmecesi}

Vatan Gazetesi, kaynağı açıklamadan Amerikan şirketi ile Türk Hükümeti arasında Atatürk filmi ile ilgili bir sözleşme imzalandığını duyurmuştur. Atatürk filminin senaryosunun Türk yetkililer denetledikten ve onayladıktan sonra çekimlere başlanacaktır. Ancak sözleşmenin filmin finansmanı ile ilgili detayları konusunda bilgi verilmemiştir. ${ }^{122}$ Atatürk filmi için Universal ile bir sözleşme imzalanmıştı ancak sözleşme ile ilgili hiçbir detay bilinmemektedir. Özellikle filmin finansmanını kimin karşılayacağı karanlıktır. Bu yüzden basında spekülasyonlar yapılmıştır. Akis Dergisine göre, Universal'in fakir ve küçük bir şirket olduğu için Atatürk filmi teklifi Türkiye'den gelmiştir. ${ }^{123}$ Akis dergisi, daha henüz Amerikalıların Türkiye ziyareti sırasında Atatürk filmi çevirme önerisinin Türkiye'nin yaptığını duyurmuştur. Universal Şirketi de kendine yapılan bu teklifi kabul etmiştir. Akis dergisine göre, Universal filmi kendi malî imkânlarıyla çevirmeyecek, Türk hükümeti büyük oranda destek olacaktır. Bu büyük mali desteğin karşılığı olarak senaryo ve Atatürk rolü dahil olmak üzere film ile ilgili önemli kararlar, Türk hükümetinin onayından geçecektir. ${ }^{124}$

119 Emin Çölaşan, Unutulmayan Söyleşiler, Tarihe Düşülen Notlar, 7.Baskı, Doğan Kitap, İstanbul, Haziran 2006, s.111-140.

120 "Yurtta Olup Bitenler" Akis Dergisi, Sayı:302, 5 Haziran 1960, s.19.

121 Emin Çölaşan, Unutulmayan Söyleşiler, Tarihe Düşülen Notlar, 7.Baskı, Doğan Kitap, İstanbul, Haziran 2006, s.141-144.

122 Vatan Gazetesi, 22 Kasım 1955,s.2

123 "Atatürk Filmi" Akis Dergisi, Sayı:93, 18 Şubat 1956, s. 24-25.

124 Akis Dergisi, Sayı:81, 26 Kasım 1955, s.12. 
Adil Özkaptan ise, filmin Türk hükümeti tarafından finanse edileceği iddialarını yalanlamıştır. ${ }^{125}$ Ancak Ahmet Emin Yalman, Amerika seyahatinde sözleşme ile ilgili Amerikalı yapımcılardan edindiği bir takım bilgiler, Adil Özkaptan'ı doğrulamamaktadır. Universal, Türkiye'nin Atatürk filmi için bir milyon lira masrafa girmesi ve geniş ölçüde askeri kıtaları Çanakkale ve İstiklâl harbi devirlerinin kıyafeti ile harekete geçirmesi esası üzerine bir sözleşme yapmıştır. ${ }^{126}$ Sözleşmeyi feshederken makamların çıkardıkları güçlükleri ve Türkiye'de anlayan anlamayan birçok kişinin müdahaleye kalkışmasını gerekçe gösteren Universal, kendi öz kaynakları ile böyle bir film projesine kalkışmadığı ortadadır. Atatürk filmini kazançlı bir proje olarak gören bir şirket, zaten Türk hükümetinin iznine ihtiyaç duymazdı. Kısacası, Türk hükümetinin finansmanı ile Atatürk filminin çekileceği muhakkaktır.

\section{Projenin Sonu}

27 Aralık 1956 tarihli gazetelerde, Atatürk filmi ile ilgili yeni bilgiler ve çalışma takvimi haberi yayınlanmıştır. Senarist Borden Chase, 620 sayfa tutacağı tahmin edilen senaryonun 550 sayfasını tamamlamıştır. Kısa sürede tamamlanacak senaryo, Türkiye'de ilgili makamlar tarafından incelenecek ve ayrıca Atatürk'ün yakını olup da hayatta bulunanlara gösterilecektir. Bütün bu işler 15 Şubat 1957'ye kadar sona erdirilecek ve teknik hazırlıklara başlamak üzere, 85 kişilik bir heyet 1 Mart 1957'de Türkiye'ye gelecektir. Filmin çekilmesine 1 Haziran'da başlanacaktır. Film için, İstanbul, Çanakkale, Eskişehir, Ankara, İzmir, Samsun Erzurum ve Sivas'ta çalışmalar yapılacaktır. Filmde 9 yabancı sanatçı rol alacak ve diğerleri Türk oyuncular tarafından canlandırılacaktır. Türk oyunculara, rolleri İngilizce olarak ezberlettirilecektir. Filmin teknik kadrosundaki 85 Amerikalı uzmana Türkiye'den 200 teknisyen katılacaktır. Yönetmen Aaron Rosenberg olmuştur. Filmin uzunluğu 3 saat 20 dakika olacaktı ve maliyeti ise 6 milyon dolara çıkmıştır. ${ }^{127}$ Mart 1957 tarihinde 632 sayfadan oluşan senaryo Ankara'ya getirilmiştir. Başta Cumhurbaşkanı Celal Bayar olmak üzere Türk yetkililer son defa senaryoyu gözden geçireceklerdir. Senaryonun onaylanmasının ardından Universal film yetkilileri, Washington'da basın toplantısı ile Atatürk filmini ve başrol oyuncusunu dünya kamuoyuna açıklayacaklardır. ${ }^{128}$ Henüz çekim aşamasına geçilmeyen Atatürk filmi için Universal şirketinin 300.000 dolar harcadığı iddia edilmiştir. ${ }^{129}$

Ancak bütün bu çekim takvimleri uygulanamamıştır. Senaryo aşaması bir türlü geçilememiştir. Senaryonun onaylanması konusunda sıkıntılar yaşanmıştır. Muhtemelen Türk yetkililer için senaryodaki sıkıntı, Atatürk'ün "bir insan" olarak gösterilmesidir. Ahmet Emin Yalman'ın görüştüğü Amerikalı film yapımcıları, senaryo anlaşmazlığından bahsetmişlerdir. Amaçlarının seyircilere Atatürk'ün kahramanlıklarını izletmek ve beğendirmek olduğunu, Atatürk'ü kusurlu göstermek gibi bir amaçlarının olmadığını söylemişlerdir. Türklerin Atatürk'ü mukaddes bir varlık olarak gördüklerini ancak filmde, Atatürk "insan" olarak görünmezse, yaşadığı duygusal çelişkiler kapalı geçilirse filmin sönük ve zayıf kalacağını anlatmışlardır. Amerikalılar, Türk yetkililerin senaryoya müsamahasız bakışından ve sansürden şikâyetçidir. Türk yetkililerin kamuoyunun eleştirisinden çekinerek senaryoyu budamaları Amerikalıların hevesini kaçırmaktadır. Yalman, zaman kaybından ötürü Amerikalıların bu işten vazgeçebileceklerini yazmıştır.

125 Milliyet Gazetesi, 4 Aralık 1955, s.1; Dünya Gazetesi 4 Aralık 1955, s.1.

126 Ahmet Emin Yalman," Atatürk Filmi," Yalman Amerika'dan Yazıyor-11, Vatan Gazetesi, 20 Mayıs 1958, s.2. 127 Cumhuriyet Gazetesi, 27 Aralık 1956. s..5.

128 Akşam Gazetesi, 3 Mart 1957, s.1.

129 Ahmet Emin Yalman, “Atatürk Filmi Mutlaka Yapılmalı," Yalman Hollywood'da-10, Vatan Gazetesi, 25 Haziran 1957, s.4. 
Amerikalılar sansür şikâyeti dışında Yunan kartını da oynamışlardır. Universal Şirketine göre; Türkiye'nin geleneksel düşmanı Yunanlar, Atatürk filminin yapılmaması için her türlü gayreti göstermektedirler, her türlü baskı ve tehdit araçlarına başvurmaktadırlar. Hatta Yunan hükümetinin resmi sözcüleri mektuplar yazarak Atatürk filminin yapılmaması için çalışmaktadırlar. Universal Şirketi, elbette Yunan tehditlerine boyun eğmemektedir. ${ }^{130}$

$\mathrm{Bu}$ arada Universal şirketi mali açıdan sarsılmış, Atatürk filminin senaristi Bordon Chase ve yönetmeni Rosenberg Universal'den ayrılmıştır. Yazdığı senaryoya karşılık 150.000 dolar alan Bordon Chase'in derin bir kederi ve acısı vardır. Yalman'a göre, Chase, filmin yapılamamasına Atatürk'e ve Türkiye'ye sevgisi nedeniyle üzülmektedir. Ahmet Emin Yalman, başka bir film şirketinin Atatürk filmi için harekete geçtiğini, Türkiye'den para yardımı beklemeden bütün masrafları yapmaya hazır olduğunu yazmaktadır. Ancak adını açıklamadığı şirket, Adil Özkaptan'la yapılan anlaşmanın yeni duruma göre tadil edilmesini ve Atatürk filmin Türkiye'de çevrilmesine Türk hükümetinin izin vermesini beklemektedir. ${ }^{131} 1958$ yılının Haziran ayının başlarında Universal International Film Şirketi, Atatürk filminin sözleşmesini feshettiğini duyurmuştur. Universal International Şirketi, sözleşmeyi feshetme nedeni bazı makamların çıkardıkları güçlükler ve Türkiye'de anlayan anlamayan birçok kişinin müdahaleye kalkışması olarak açıklanmıştır. ${ }^{132}$ Demokrat Parti'nin dört yıl süren kurmaca Atatürk filmi girişimleri böylelikle son bulmuştur.

\section{Sonuç}

Devlet adamları ve tarihi kişiliklerin yaşam öyküsü, daima sinema sektörünün ilgisini çeken konular arasında yer almıştır. Dünya sinema tarihinde biyografi türünde çok sayıda film çekilmiştir. Tarihin akışını değiştiren büyük bir özne olarak Mustafa Kemal Atatürk'ün yaşam öyküsünün beyazperdeye aktarılması sinema sektörü için heyecan verici bir proje olması doğaldır. 1950'li yıllarda Demokrat Parti iktidarı, Atatürk'ün hayatını beyazperdede canlandıracak bir kurmaca film projesi için harekete geçse de başarılı olamamıştır. Üstelik bu satırların yazıldığı 2020 yılına kadar da Atatürk'ün hayatı veya hayatının bir bölümü ile ilgili pek çok belgesel yapılmasına karşın kurmaca bir film çekilememiştir. Elbette Atatürk'ün bir aktör tarafından canlandırıldığı kurmaca filmler olmuştur. Ancak bu filmlerin öyküsünün odağında Atatürk'ün hayatı olmamıştır.

Demokrat Parti döneminde Atatürk film projelerinin fikir babası Cumhurbaşkanı Celal Bayar olmuştur. Adil Özkaptan aracılığı ile iki kez Amerikalılara Atatürk filmi sipariş edilmiştir. Bu filmlerinin finansmanını Türkiye Cumhuriyeti Hükümetinin karşılayacağı muhakkaktır. Projeler finansman anlaşmazlığından değil senaryo aşamasında iken feshedilmiştir. Sunulan senaryoların beğenilmemesi ve sürekli değişiklik talep edilmesi nedeniyle sözleşmeyi fesheden taraf şirketler olmuştur.

Atatürk'ün hayatını ve hayatının bir dönemine odaklanan kurmaca bir filmde başkarakter elbette Atatürk olmalıdır. Dramatik yapılı filmlerde başkarakterler en çok iç ve dış çatışmayı yaşayan kişidir. Dramatik yapılı filmlerde, amacı olan ve nedensel motivasyonu kusursuz karakter, karşısına çıkan bütün engeller ile çatışarak onları alt etmeyi başarır ve amacına ulaşır. Atatürk'ün hayatı, dramatik yapılı bir film için biçilmiş kaftandır. Ancak başkarakterin iç çatışma yaşaması, korku, hayal kırıklığı, tereddüt, acı, iç sıkıntısı gibi duyguları da hissetmesi gerekir. Çok boyutlu bir karakter yaratmanın şartı

130 Ahmet Emin Yalman, “Atatürk Filmi Mutlaka Yapılmalı,” Yalman Hollywood’da-10, Vatan Gazetesi, 25 Haziran 1957, s.4.

131 Ahmet Emin Yalman," Atatürk Filmi," Yalman Amerika'dan Yazıyor-11, Vatan Gazetesi, 20 Mayıs 1958, s.2.

132 Cumhuriyet Gazetesi, 5 Haziran 1958. s.1 
olan iç çatışma, ana akım sinemada karakterin inandırıcı olmasını ve seyircinin karakter ile özdeşleşmesini sağlayan en etkili yoldur. Dönemin Universal Şirketinin yöneticilerinin de ifade ettiği gibi iç çatışma olmaz, Atatürk "insan" olarak görünmezse, film sönük ve zayıf kalabilirdi. Oysa Türk kamuoyunun önemli bir kısmı, Atatürk'ü "sıradan bir insana" yaklaştıracak durumlar ve duygular içinde betimlediği takdirde filmi, kusurlu bir Atatürk tasviri olarak değerlendirmesi mümkündü. Toplumun büyük çoğunluğunun kurucu lider olmanın ötesinde "Halaskar Gazi" ve "Kahraman" olarak gördüğü Atatürk'ü beyazperdede "duygusal çelişkiler" içinde göstermek Türk kamuoyunu memnun etmeyebilir hatta hayal kırıkığına uğratabilirdi. Kamuoyunun tepkisinden çekinen Demokrat Parti iktidarı, hazırlanan senaryolara müsamahasız yaklaşmış ve "zaaf" olarak nitelendirilecek tüm unsurları çıkararak senaryoları reddetmiştir. Zorlu senaryo sürecini aşamayan Amerikan yapım şirketleri de sözleşmeleri feshetmiştir. Atatürk'ün hayatına dair film projesi, Demokrat Parti döneminden sonra da zaman zaman gündeme gelmiştir. Ancak bu projeler de hayata geçirilememiştir.

CHP ile Atatürk'ün devrimlerine sadık kalma ve hatırasına sahip çıkma rekabetini başlatan Demokrat Parti, Atatürk'ün hayatını beyazperdede canlandırmayı hedeflemiştir. Atatürk filmi projesinin CHP ile rekabet yönünden siyasal nedenleri olduğu kadar Atatürk'e ve fikirlerine şüphesiz bağlı olan Cumhurbaşkanı Bayar'ın samimi çabası da etkendir. Ancak Atatürk filmi projesi, kamuoyundan gelebilecek olumsuz eleştirileri göze alamayan Demokrat Parti iktidarının tavrı nedeniyle gerçekleşememiştir.

\section{Kaynakça}

Ahmad, Feroz, (1996), Demokrasi Sürecinde Türkiye 1945-1980, Çev: Ahmet Fethi, Hil Yayınları, İstanbul, 1996.

Boran, Tunç, (2011), Mekân ve Siyaset Bağlamında Anıtkabir, Yayınlanmamış Doktora Tezi, Ankara: Ankara Üniversitesi Türk İnkılap Tarihi Enstitüsü, Ankara, 2011.

Boran, Tunç, (2020), "Türk Sinema Tarihinden İlgi Çekici Bir İddianın İncelenmesi," Türk Sinema Tarihine Farklı Bakışlar, Detay Yayıncılık, Ankara,2020.

Cem, Cemil Cahit, (1955), “Atatürk Filmi Meselesi,” Bana Sor, Milliyet Gazetesi, 22 Ekim 1955, s.3.

Çölaşan, Emin, (2006), Unutulmayan Söyleşiler, Tarihe Düşülen Notlar, 7.Baskı, Doğan Kitap, İstanbul, Haziran 2006.

Deniz, Ümit, (1955), “Atatürk Filmi Hakkında Halkımız Ne Düşünüyor," Milliyet Gazetesi, 8 Kasım 1955, s.3.

Erdem, Erden Eren, (2016), "Türkiye-ABD Illişkilerinin Zirve Noktası: Celal Bayar'ın ABD Ziyareti," Türkiye'nin 1950'li Yılları, Iletişim Yayınları, İstanbul, 2016.

Eroğul, Cem, (1992), "Çok Partili Düzenin Kuruluşu 1945- 71," Geçiş Sürecinde Türkiye, Belge Yayınları, İstanbul, 1992.

Felek, Burhan, (1954), “Küçük Fairbanks," Hadiseler Arasında Felek, Cumhuriyet Gazetesi, 17 Ağustos 1954, s.3.

G., C., (1957), “Atatürk Filmini biz çevirmeliyiz" Pazar Postası, 10 Kasım 1957, s.3.

Hakan, Fikret, (2012), Türk Sinema Tarihi, İnkılap Kitabevi, İstanbul, 2012.

Kakınç, Tarık Dursun, (1956), "Sinema Notları," Pazar Postası, 10 Haziran 1956, s.8-11.

Kakınç, Tarık Dursun, (1957), "Yılan Hikâyesi Atatürk Filmi" Pazar Postası, 10 Kasım 1957, s.3. 
Kakınç, Tarık Dursun, (1958), "Atatürk Filminin Tuzu Biberi” Pazar Postası, 6 Temmuz 1958, s.13.

Koçak, Cemil, (2006), "Tek Parti Yönetimi, Kemalizm ve Şeflik Sistemi: Ebedi Şef/Milli Şef," Modern Türkiye'de Siyasi Düşünce Cilt: 2 Kemalizm, İletişim Yayınları, İstanbul, 2006.

Onaran, Âlim Şerif, (1981), Muhsin Ertuğrul'un Sineması, Kültür Bakanlığı Yayınları, Ankara, 1981.

Özer, N., (1951), Amerikan Sinemacılığında Buhran” Yağmur ve Toprak, Sayı:26, Ocak 1951, s.25.

Özgüç, Agâh, (2012), Ansiklopedik Türk Filmleri Sözlügü, Horizon International, İstanbul, 2012.

Özgüç, Agâh, (2005), Türlerle Türk Sineması, Dünya Kitapları, İstanbul, 2005.

Özön, Nijat, (1968), Türk Sineması Kronolojisi 1895-1966, Bilgi Yayınevi, İstanbul, 1968.

Özön, Nijat, (1962), Türk Sineması Tarihi, 1896-1960, Artist Yayınları, İstanbul, 1962.

Refik, Cemal, (1962), “Atatürk Filmi,” İstanbul Hayatı, Akşam Gazetesi, 6 Aralık 1955, s.3

Safa, Peyami, (1955), "Bir Okuyucumuzun Haklı Asabiyeti," Objektif, Milliyet Gazetesi, 12 Temmuz 1955, s.2.

Scognamillo, Giovanni, (2010), Türk Sinema Tarihi, Kabalcı Yayınevi, İstanbul, 2010.

Şener, Erman, (1970), Kurtuluş Savaşı ve Sinemamı, Ahmet Sarı Matbaası, İstanbul, 1970.

Teksoy, Rekin, (2009), Sinema Tarihi Cilt:1, Oğlak Yayınları, İstanbul, 2009.

Ulunay, Refi Cevad, "Mevcud Na Mevcud," Takvimden Bir Yaprak, Milliyet Gazetesi, 4 Aralık 1954, s.3.

Ünder, Hasan, "Atatürk İmgesinin Siyasal Yaşamdaki Rolü," Modern Türkiye'de Siyasi Düşünce Cilt: 2 Kemalizm, İletişim Yayınları, İstanbul, 2006.

Yalman, Ahmet Emin, Yakın Tarihte Gördüklerim ve Geçirdiklerim 1922-1971, 2. Cilt, Pera Turizm, İstanbul, 1997.

Yalman, Ahmet Emin, "Atatürk Filmi Müşaviri Vesamet Hanımla Buluşma" Yalman Hollywood'da-8, Vatan Gazetesi, 23 Haziran 1957, s.4.

Yalman, Ahmet Emin, "Atatürk filminin senaryosunu yazan Chase'in evinde," Yalman Hollywood'da-9, Vatan Gazetesi, 24 Haziran 1957, s.4.

Yalman, Ahmet Emin, "Atatürk Filmi Mutlaka Yapılmalı," Yalman Hollywood'da-10, Vatan Gazetesi, 25 Haziran 1957, s.4.

Yalman, Ahmet Emin, "Atatürk Filminde Başrolü Kim Oynayacak? " Yalman Hollywood'da-11, Vatan Gazetesi, 26 Haziran 1957, s.4.

Yalman, Ahmet Emin, “Glenn Ford," Yalman Hollywood'da-15, Vatan Gazetesi, 30 Haziran 1957, s.4.

Yalman, Ahmet Emin, "Atatürk Filmi," Yalman Amerika'dan Yazıyor-11, Vatan Gazetesi, 20 Mayıs 1958, s.2.

Zürcher, Erik Jan, Modernleşen Türkiye'nin Tarihi, Çev: Yasemin Saner Gönen, İletişim Yayınları, İstanbul, 2007.

\section{Dergi ve Gazeteler}

Akis Dergisi

Akşam Gazetesi 
Demokrat Parti'nin Atatürk Filmi Projeleri

Cumhuriyet Gazetesi

Dünya Gazetesi

Milliyet Gazetesi

Pazar Postası

Ulus Gazetesi

Vatan Gazetesi

Yağmur ve Toprak

Zafer Gazetesi 